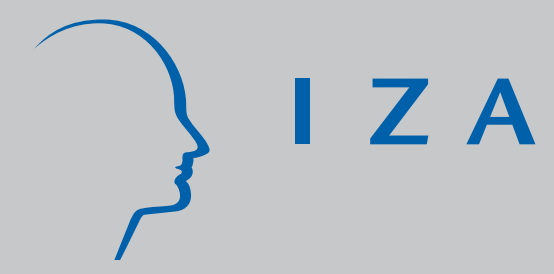

IZADP No. 4149

Do the Obese Really Die Younger or Do Health Expenditures Buy Them Extra Years?

Paul Frijters

J uan Baron

April 2009 


\title{
Do the Obese Really Die Younger or Do Health Expenditures Buy Them Extra Years?
}

\author{
Paul Frijters \\ Queensland University of Technology \\ Juan Baron \\ Banco de la República, Colombia, \\ Australian National University and IZA
}

Discussion Paper No. 4149

April 2009

IZA

P.O. Box 7240

53072 Bonn

Germany

Phone: +49-228-3894-0

Fax: +49-228-3894-180

E-mail: iza@iza.org

\begin{abstract}
Any opinions expressed here are those of the author(s) and not those of IZA. Research published in this series may include views on policy, but the institute itself takes no institutional policy positions.

The Institute for the Study of Labor (IZA) in Bonn is a local and virtual international research center and a place of communication between science, politics and business. IZA is an independent nonprofit organization supported by Deutsche Post Foundation. The center is associated with the University of Bonn and offers a stimulating research environment through its international network, workshops and conferences, data service, project support, research visits and doctoral program. IZA engages in (i) original and internationally competitive research in all fields of labor economics, (ii) development of policy concepts, and (iii) dissemination of research results and concepts to the interested public.
\end{abstract}

IZA Discussion Papers often represent preliminary work and are circulated to encourage discussion. Citation of such a paper should account for its provisional character. A revised version may be available directly from the author. 


\section{ABSTRACT}

\section{Do the Obese Really Die Younger or Do Health Expenditures Buy Them Extra Years?}

A recent debate in the medical literature has arisen around the mortality effects of obesity. Whereas it has been argued that the obese die younger, the data that have become available do not immediately support this. This potentially undermines the hypothesis that modern life with its physical ease and cheap food would eventually make us die younger, and undermines the notion that economic growth comes with health warnings. We revisit this debate going over the mortality effects of obesity, using the US Health and Retirement Study. Whilst we find that obesity leads to chronic diseases that reduce length of life, we also find that the obese survive strokes and lung disease more often than the non-obese. A possible explanation is that the obese are under greater medical scrutiny, meaning that lung disease is more quickly diagnosed. This result holds when controlling for smoking and the long-term effects of obesity.

JEL Classification: I10, I18, C23

Keywords: obesity, longitudinal data, mortality, smoking, reverse-causality

Corresponding author:

Juan Baron

Calle 33 \# 3-123 (Centro)

Cartagena de Indias

Colombia

E-mail: jbaronri@banrep.gov.co 


\section{Introduction}

Until quite recently, medical authorities and medical researchers were fairly united in the finding that being overweight or obese was bad for us in nearly all ways imaginable. Obesity would causally increase the risk of type II diabetes, heart disease, the advent of chronic illnesses, deterioration in the arteries, etc. Via these effects, obesity would cost up to 13 years of life (Fontaine et al 2003). As a result, the World Health Organisation gives an official warning regarding the obesity 'epidemic' and lists no less than 30 diseases that are causally related to obesity (World Health Organization, 2000).

The consensus on the adverse effects of obesity has had profound implications for health policy and for the projections of future health costs. ${ }^{1}$ For one, the consensus lead to expensive programs of trying to get people to lead more active lifestyles and have lead to calls to tax fast food. Also, the link between obesity and lifestyle has been used to argue that humanity pays a health price for economic development, even to the extent that Olshansky et al. (2005) projected that the steady increase in life expectancy during the last two centuries will stop due to the obesity epidemic. Add to this that future life expectancy is perhaps the most important variable that goes into the planning of the health and retirement system and given that the prevalence of obesity seems almost certain to increase in the coming decades, this makes it of eminent policy importance to get at the bottom of the obesity-life expectancy issue.

In 2005 a chink emerged in the almost unanimous condemnation of being 'heavy', though the chink mainly related to being overweight and not obesity. ${ }^{2}$ Using data from the National Health and Nutrition Examination Survey (NHANES I, II, III), which is a representative cross-section of the US population, Flegal et al. (2005) found that overweight people exhibit a lower risk of premature death compared to people with a normal Body Mass Index (BMI); the excess deaths due to overweight were in fact negative. In addition, their estimate of excess deaths for obese people was substantially

\footnotetext{
${ }^{1}$ For a discussion of the costs of obesity and other circumstances, see Sturm (2002).

2 At that time, several studies documenting the relationship between BMI and mortality using nonrepresentative samples of the US population had been published. See for example Calle et al. (2005), Calle et al. (1999), Manson et al. (1999), and Manson (1995). Flegal et al. (2004) argues that studies estimating excess deaths due to obesity should use samples that are representative of the mortality experience of the population in the United States.
} 
lower than in previous studies $(112,000$ compared to 350,000 for the year 2000) though still positive. ${ }^{3}$ Whilst that paper focussed almost entirely on being overweight, this paper will address the mortality effects of obesity in the confines of a panel setting where we are able to follow individuals continuously until death. Our findings differ from Flegal et al. (2005) in that we find no excess deaths from obesity at all. We further expand on Flegal et al. $(2005,2007)$ by addressing the hypothesis that the increases in medical expenditures in the last 30 years have been particularly beneficial to the obese.

Our dataset is the US Health and Retirement Study which we use to systematically study whether obesity leads to shorter lives and, if not, what the probable pathways are via which obesity is good for ones life expectancy. This dataset is ideal because it follows the same individuals for up to 14 years and yet is rich in doctor-identified health measures as well as socio-economic measures and health expenditures.

We start our investigation in Section 2 by seeing if there is any potential story at all, i.e. whether it is the case that the obese indeed live just as long as the non-obese. It turns out that the obese live significantly longer than the non-obese in our data, not just if we look at recent obesity but even if we look at obesity in the past.

We then look at whether we can replicate the initial reasons for researchers to believe that obesity might reduce life expectancy because of its relation with various diseases. To this end we look at which diseases are correlated and longitudinally related to obesity in the HRS, finding indeed that the obese are more likely to suffer from various diseases such as diabetes, arthritis, and high blood pressure. In a sense this means our dataset contains the core puzzle that needs to be answered, i.e. that the obese suffer from more diseases but still don not seem to die younger.

In consecutive subsections we then address the main concerns that medical scholars have expressed as to why one would fail to pick up a mortality increasing effect of obesity.

\footnotetext{
${ }^{3}$ The popular media quickly picked up the results from this article to call into question the detrimental effects of obesity. See, for example Kingsland (2005) and Kolata (2007). After the publication of this article a huge debate regarding Flegal's et al. finding emerged in the medical profession. See for example Kolata (2005), Couzin (2005), and Harvard School of Public health (2005). Flegal et al. (2007) then expanded their analysis to the relationship between BMI and cause-specific mortality, finding that overweight people were less likely to die from non-cancer and non-Cardio Vascular Disease (CVD) but not reporting any specific benefits of obesity.
} 
This includes the hypothesis that there are confounding aspects like smoking (smoking makes you thin!) that, when not adequately dealt with, would lead to a spurious positive relation between obesity and length of life (Calle et al. 1999, Manson et al. 1995); and it includes the hypothesis that there is a reverse causality problem in that those close to death lose weight rapidly, making it hard to ascertain the independent effect of obesity. ${ }^{4}$

Whilst examining the reasons why the raw relation might be biased, we simultaneously address possible explanations for why the raw relation might simply be a reflection of mortality benefits of obesity. To this end we examine three important possibilities. The first is that the obese are less likely to become smokers because, in a sense, they already have an addiction. The second is that it might be the case that obesity makes one more likely to survive particular diseases because of the greater mass of fuel stored allowing a patient to survive thinning for longer. The final one is that the greater medical attention going to the obese has meant that particular health problems are diagnosed earlier and are thus more effectively treated for the obese than the non-obese. ${ }^{5}$

The main contribution of this paper is that it is the first to address the most prevalent hypotheses regarding the mortality effects of obesity for a single dataset, simultaneously adding the importance of prevention and medical expenses to the possible explanations.

The outline of this paper is as follows. The next section introduces our dataset and gives some very basic sample statistics to ascertain that our longitudinal dataset in broad outlines gives similar cross-sectional results as those used hitherto in this literature. Section 3 then systematically addresses all the various possibilities mentioned in the literature for why obesity might reduce length-of life, and whether these hold up to closer scrutiny. There, we also extend on the previous literature by looking at whether we can identify any positive effects of obesity, such as a reduced probability of becoming a smoker and a smaller chance of dying from certain chronic diseases. Section 4 concludes.

\footnotetext{
${ }^{4}$ Lawlor et al., 2006 studies these issues using "community-based" data from Scotland.

${ }^{5}$ There is a large literature on obesity-relevant medical advances in the last 30 years, including the increased use of carotid endarterectomy procedures or heart transplants (Pamuk et al. 1998; American Heart Foundation, 2006; Livingston, 2007; National Center for Health Statistics, 2007), the increases in the use of blood thinners (Mehta et al. 2006), and the increased use of bariatric surgery (Buchwald et al., 2004).
} 


\section{The Health and Retirement Study (HRS)}

To analyse obesity mortality we use data from the first eight waves of the Health and Retirement Study (HRS). The HRS is a longitudinal study with a core sample representative of the US population over the age of 50 that are interviewed once every two years, and includes a rich set of health characteristics, notably BMI at each interview, smoking, and information on doctor-diagnosed long-term health conditions. ${ }^{6}$ The survey also collects detailed information on a broad spectrum of socio-economic characteristics, such as income, wealth, job information, and retirement. Our sample consists of all individuals ever included in the sample who have complete information on the variables of interest. The sample includes many younger individuals who are partnered to the individuals in the core sample.

It is important to point out that it hardly matters to a study of mortality that the young are under-represented, simply because the odds of dying before 50 of a health-related problem are minimal (discounting child deaths). In 2005, only 4 per 1000 individuals between the age of 1 and 45 died, and only 8.5 per 1000 between 1 and 55 did. Of these deaths before 45, about half is due to accidents, homicide or suicide. Hence only about 3 in 1000 people die due to non-birth health-related deaths before the age of 51 (Kung, 2005). More worrying than lacking many youngsters in our data is that we do not have information about the height and weight of individuals when they were young, and hence are not able to ascertain the effect of childhood obesity on old-age mortality.

The HRS started in 1992 with a single cohort born between 1931 and 1941. After this year, four more cohorts have been included: 1) born before 1924 (from the Study of Assets and Health Dynamics Among the Oldest Old, 1993); 2) born between 1924 and 1930 (added in 1998); 3) born between 1942 and 1947 (added in 1998); and 4) those born between 1958 and 1953 (added in 2004). Our sample, therefore, covers the period 19922006 and contains 30,405 people in total.

\footnotetext{
${ }^{6}$ For more information about the HRS visit: http://hrsonline.isr.umich.edu/.
} 
The number of deaths starting from wave 2 is $229,1080,1318,1392,1530,1275$, and 1370 in wave 8 . In total there are 8154 deaths, approximately 27 per cent of the total number of people ever included in the sample, which is certainly high enough to do meaningful analyses on.

The first thing we investigate is how the probability of dying differs for obese and nonobese people across the years. Table 1 shows the probability of dying in the current period conditional upon being obese/non-obese two years before death $(t-1)$, four years before death $(t-2)$, and so forth. Following standard practice in the literature an individual is considered obese if his Body Mass Index (BMI) exceeds $30 .^{7}$ The fourth column in the table reports the difference in the probability of dying between the obese and the non-obese and, in column 5, it shows the p-value for the hypothesis of this difference being equal to zero. The figures show that those considered obese exhibit a lower probability of dying at time $t$. People who were non-obese two years before dying $(t-1)$, for example, had a 5.81 percent probability of dying compared to a 3.06 per cent probability for the obese, making the obese 2.6 percentage points less likely to die next period than the non-obese. If we go back further in time, we observe the same direction of correlation though the magnitudes become smaller: those who were obese 12 years previously still show a 0.5 percentage point lower probability of dying 12 years later than the non-obese.

\section{[Table 1 here]}

The raw relation in our data is thus indeed that the obese tend to live longer than the nonobese. The next question is whether they nevertheless suffer from more health conditions. Table 2 shows for the obese and non-obese the probably of having experienced various health problems since the last interview, i.e. in the 2 years preceding the interview. From the table we see that the obese are 18 percentage points more likely to have experienced high blood pressure in the current period; 14 percentage points more likely to have experienced diabetes; 1.2 percentage points more likely to have experienced chronic lung

\footnotetext{
${ }^{7}$ The BMI is calculated as the ratio between an individual's weight in kilograms and their height in meters squared.
} 
disease; 1.9 percentage points more likely to have experienced a heart attack (and related diseases); 3.7 percentage points more likely to have experienced emotional/psychiatric problems; and 13 percentage points more likely to have experienced arthritis. The obese, nevertheless, are 1.2 percentage points less likely to have developed cancer and 0.6 less likely to have had a stroke. If we would simply add up the believed mortality effects of each of these diseases for the obese and the non-obese, an obese individual would live 2.4 less years than a non-obese individual. ${ }^{8}$

[Table 2 here]

The conclusion from the simple statistics in Tables 1 and 2 is that in our dataset too, there is a puzzle: the obese do not seem to die younger (indeed they are less likely to die) even though they identifiably are more likely to suffer from several severe diseases. Since these data are distinct from those used previously and is designed to be representative of the population over 51, these simple statistics severely weaken the potential criticism that the health benefits from being heavy were only to be found in the dataset used by Flegal et al. (2005).

\section{Analyses}

We address two main critiques that one can have against the raw findings above, both in the direction of arguing the presence of reverse causality. The first is that smoking reduces BMI and thus makes a person less likely to be obese whilst smoking is undoubtedly detrimental to length of life. Not accounting for smoking then could lead to the effects of obesity being more about 'not being a smoker' rather than being obese per se. The second potential critique is that death may be associated with thinning beforehand, again causing reverse causality problems.

Smoking and other confounding pathways

\footnotetext{
${ }^{8}$ Calculated as the product between the difference in probability for obese and non-obese people in Table 2 and the average years of life lost per person due to (i) diabetes, (ii) chronic lung disease and (iii) heart attack, using the estimates of Ries et al. (2007) for their mortality effect.
} 
It is important to note that the lack of 'controlling' for confounding variables like smoking does not immediately lead to an obvious bias: it is indeed the case that the obese smoke less than the non-obese (see Table 2; Manson et al., 2005; Calle et al. 1999) and its true that the smokers die earlier (e.g. Sloan et al. 2004 and the references therein), but that does not necessarily bias anything in any particular direction unless one knows the direction of causality (for an early discussion, see Arday et al. 1995). The bias in the direction of finding an inflated positive effect of obesity on life expectation due to smoking only holds if smoking causally leads to less weight. If it is alternatively the case that obesity is a 'different addiction' to smoking and that it is on the aggregate true that being obese 'protects one' against becoming a smoker in the first place, then one simply has found a causal pathway via which obesity leads to higher life expectancy. It needs an empirical analysis to see how strong these conflicting possibilities are.

We thus examine three distinct aspects of the possible importance of smoking and other confounders: 1) how much smoking explains; 2) whether smoking leads to lower obesity and whether higher obesity leads to a lower probability of starting to smoke; and 3) how robust is the relationship to the inclusion of a variety of other individual characteristics such as initial wealth.

We begin by investigating the role of smoking in the relationship between mortality and obesity. Table 3 a presents Probit estimates where the dependent variable is death before the start of the interview, i.e. death in the last two years. The variables included by necessity relate to circumstances in previous periods, where we are particularly concerned with the effects of obesity after adding smoking related variables. The key variable we are interested in is the coefficient on the lag of the obesity variables because that one denotes what the effect is of changing obesity from 0 to 1 in all previous periods. The other obesity variables are changes in obesity and thus are not related to the long-run effect of obesity (when all changes become 0) but to short-run effects.

Models 1 to 4 in the table include obesity and age. Even after controlling for age, we observe a negative coefficient on the obesity variables; the coefficients, however, are only statistically significant for obesity two and four years ago. By including all the obesity history variables, we can estimate the long-run impact of being obese (Model 4) which we still find to be negative but insignificant (an effect of -0.039). The coefficients 
on the changes indicate that there is a health benefit from becoming obese, which seems quite likely due to reverse causality. Just as a robustness check, we re-run our Probit model replacing the obesity dummy variables by the actual BMI value. The advantage of this approach is that it uses all the variation in the BMI measure. The BMI model in the table shows qualitative similar results to the model with obesity dummy variables. The long-run effect of BMI (the coefficient on the last included lag) is again negative, and this time statistically significant, but small. What this table shows is that controlling for age or the history of obesity does not take away the finding that there is no life expectancy reduction from obesity.

\section{[Table 3a here]}

We now ask what happens to the relationship between obesity and mortality when we add smoking histories. Table $3 \mathrm{~b}$ shows estimates similar to the ones in Table $3 \mathrm{a}$ but includes individuals' smoking histories. First of all, smoking increases the probability of dying next period no matter when the smoking was done. All coefficients on the smoking variables are strongly statistically significant (Models 1 to 5).

By comparing the coefficients on obesity in Tables 3a and 3b (Models 1 to 3) we can also see that including smoking reduces the effect of obesity on mortality in such a way that only being obese in the period immediately before dying still has a negative effect on the probability of dying. In the extended model 4, the long-run effect of being obese in the past becomes positive but very small (0.004) and statistically insignificant. When using BMI instead of obesity, the relation again becomes negative, though insignificant.

Hence adding smoking to the regression does weaken the initial finding that obesity increases length of life but does not make enough difference to get the finding that obesity reduces length of life.

[Table $3 b$ here]

Then there is the issue of direction of causality. We now exploit the longitudinal aspect of our data where we try to explain the current smoking and obesity situation by means of 
the situation in the previous period, attempting to see whether smoking reduces the odds of being obese or whether the reverse might also be true. Table 4 shows several models for the effect of smoking on obesity (first three columns) and for the effect of obesity on smoking behaviour.

We first discuss the relationship between obesity and smoking. We run two types of models: one where the dependent variable, obesity, is dichotomous (Probit model) and a GLS model where instead of obesity we use individuals' BMI. In both models we include lags of the dependent variable and control for age. In both these models, we find that the impact of long-term smoking, which is given by the sum of the coefficients of the individual smoking variables, is negatively and statistically associated with being obese or BMI. In particular we find that long-term smoking reduces the chance of becoming obese by only 1.1 percent. From the BMI model, we can also see that long-term smoking reduces BMI significantly but only by 0.13 . In addition to these two models, we also run a GLS model of the change in BMI on current smoking and smoking in the last period. We find in this case, however, no association between smoking and change in BMI. ${ }^{9}$

Columns 3 to 6 in Table 4 report Probit estimates for current smoking. The first model includes obesity history (as reflected by obese dummy variables) and smoking history. The second model uses BMI instead of obesity dummy variables. Both models suggest a negative relationship between long-term obesity and smoking behaviour, although in both cases the long-run effects are not statistically significant at standard levels. The last model we estimate is a Probit model for smoking using as regressors only short-term smoking and short-term BMI. In this case we do find a statistically significant relationship between BMI today and smoking two years later (coefficient $=-0.010$, $\mathrm{z}=6.23$ ). Translated to marginal effects, this implies that having a 1 point higher BMI today reduces the probability of being a smoker the next period by approximately 2.1 percent.

Whilst the results above suggest that obesity might well indeed lead to a reduced probability of smoking, we do not put too much weight on that possibility, mainly

\footnotetext{
${ }^{9}$ Flegal (2007) also looks at the relationship between changes in smoking and changes in obesity and finds no significative correlation.
} 
because we do not have truly 'independent' random shocks to smoking and obesity via which to tease out causality convincingly. It is however hard to imagine data that would have true random variation in obesity over time: no random event that we know of can make individuals become obese overnight.

[Table 4]

Finally, as Appendix Table A1 shows, the relationships above are robust to the inclusion of a large variety of individual factors, such as initial levels of income, wealth, education, ethnicity and gender. We may mention that the results are also robust to more flexible age-specifications (available on request).

\section{Thinning before death and obesity}

Another important potential critique of the raw finding that the obese live longer is that imminent death causes people who were obese to become thin. ${ }^{10}$ Before examining this empirically, it is handy to reflect on the circumstances in which this would actually lead to the 'reverse bias' of death causing thinness rather than the other way around. The circumstances in which obese people would lose weight before death but where their obesity does not prevent earlier death are very peculiar indeed because they would require that those who did not have excess weight to lose but who did suffer from the same disease are in no way more likely to die than those that do have excess weight. Since the body dies if it runs out of all fuel, the 'reverse causality story' can only be true if there is some kind of 'plateau weight' at which the thinning stops and to which all individuals with a disease are moving. This is certainly not intuitively plausible. It is perhaps more plausible to think that there is no such plateau and that death becomes ever more probable as the body runs out of fuel, i.e. the thinner a person becomes. In that case, there is in fact a health benefit of obesity: obesity is then merely stored fuel useful for surviving a little longer.

\footnotetext{
${ }^{10}$ This is the argument behind the studies by Manson et al. (1995) and Calle et al (1999). They argue that if obese people with a history of disease are not excluded from the baseline sample that would create a misleading correlation between BMI and mortality.
} 
As an initial ocular test of whether death is associated with thinning at all, Figure 1 shows the development of BMI by age for all those in the sample and for those known to die before they are 80 . We effectively see that thinning takes place for both groups in equal measure after the age of 65, though between 50 and 65 there does appear to be a greater degree of thinning for those who are known to die before their $80^{\text {th }}$. Since the vast majority of deaths occur after 65, Figure 1 already limits the degree to which one can say with confidence that death is associated with thinning to a greater degree than age is. However, the movement of BMI by age in Figure 1 is partially driven by what happens to individuals over time and partially by the fact that the individuals at the higher ages are different individuals to those at the lower ages, reducing the degree to which we can learn anything with confidence from Figure 1.

Figure 2 shows average BMIs for four groups of individuals and four periods before their death. To construct Figure 1 we keep only individuals who die and we follow them backwards in time. Then we classify as obese those who had a BMI higher than 30 at the first point in time in which they were observed in the data. We classify as ill those people who four periods before they died reported having one of the eight diseases for which there is information in the data. Figure 2 then shows the average BMI for four groups of people who die in period t by disease: 1) all obese (ill and non-ill); 2) obese and ill; 3) All non-obese; and 4) ill and non-obese.

Figure 2 shows that, effectively, all groups thin more or less at the same rate before death: the ill, the non-ill, the obese, and the non-obese all see their weight reduce closer to death. Importantly, we do not observe a strong 'plateau effect', i.e. there does not appear to be some critically low weight at which patients stop losing weight before they die. This suggests that there has to be a continued benefit of having extra weight to lose, though, again, Figure 2 is only a loose ocular test.

[Figure 1 and Figure 2]

To go beyond these somewhat inconclusive ocular tests, we look at whether the obese are more or less likely to survive particular diseases by combining all the information into Probit models of mortality. This time we include the medical history of diseases as well as interaction terms between obesity and these medical diseases. If obesity would lead to 
the ability to survive certain diseases better, this should show up as a negative sum of these interaction effects for certain diseases. By including the medical history we include the reverse-causality possibility that disease and thinning are causally related.

Table 5 presents several specifications for mortality, controlling for age, obesity in the past, chronic diseases and smoking history. As suggested by the model with no interactions, long-term obese people tend to have a lower probability of dying next period, even after controlling for age, smoking, and their eight-year history of chronic diseases. As calculated by adding the time-coefficients for the same disease in this specification (not shown in table), people who suffer from chronic diseases in the longterm are more likely to die next period, except, interestingly enough, for those with high blood pressure and arthritis.

The models in Table 5 with interactions between obesity and each of the eight chronic diseases allows the test of the hypothesis we are interested in: whether the obese are more likely to die from certain chronic disease than the non-obese. In the bottom panel of the table we report the sum of the coefficients on the interactions terms by disease. Results indicate that obese people who have a long history of diseases such as high blood pressure, diabetes, cancer, and psychiatric problems are just as likely to die next period as comparable non-obese people. We find that obese people with a history of lung disease are less likely to die (the same is true for strokes but the coefficient is statistically insignificant once we include four lags of the regressors). The long-term effect of suffering from heart disease is also sizeable and statistically significant in two of the specifications. The obese with heart conditions are, however, more likely to die next period than non-obese comparable individuals. ${ }^{11}$ Summarising, obesity appears to aggravate heart conditions, but reduces the danger coming from lung disease and maybe strokes as well. Together, the results in Figure 2 and Table 5 show that many chronic diseases are indeed related to a thinning of the obese, but that it is also the case that obesity means one lasts longer in some conditions though not in others.

\footnotetext{
${ }^{11}$ As an aside, long-term smoking is now insignificantly related to the probability of dying next period; however, this is not surprising since we are controlling for many of the potentials mechanisms through which smoking affects mortality.
} 
[Table 5 here]

Does money buy health benefits for the obese?

A final important hypothesis we wish to examine is whether increased health expenditures have lead to particular health improvements for the obese. To this end, Figure 3 shows the relation between the increased real medical expenditure on the obese versus the non-obese and the marginal mortality effect of obesity over time. The medical expenditure line is calculated as the age-adjusted mean additional expenses on the obese, whilst the marginal mortality effect of obesity is calculated by running a mortality Probit for each period including age and obesity.

Figure 3 shows what one would intuitively expect: real expenditures on the obese versus the non-obese have risen markedly since the early 1990s from a low of 778 dollars per year per obese to 2253 dollars in 2002, almost a tripling of the difference. At the same time, the marginal effect of obesity on mortality has improved, with the obese being 0.2 percent more likely to die in 1992 and 0.69 percent less likely to die in 2004. From studies of the 1970 and 1980s it is furthermore quite likely that the mortality effect of obesity before 1992 was even higher (Calle et al. 2005; Calle et al. 1999; Manson et al. 1999; and Manson 1995). The statistical relation between the two lines in Figure 3 is negative and significant at the 1 percent level, though this does not prove causality.

What could be the causal pathways consistent with our previous findings that could have lead to a positive relation between health expenditures on the obese and an emerging mortality benefit of obesity? The literature and the above findings support two possibilities: a reduction in the medical severity of obesity-related diseases and prevention effects.

\section{Reductions of the severity of obesity-related diseases}

The diseases the obese suffer from more have become less lethal than in previous decades before due to improved medication. This includes bypass operations, carotid endarterectomy procedures, and heart transplants which are expensive and have all become more common than in the past (Pamuk et al. 1998; American Heart Foundation, 2006; Livingston, 2007; National Center for Health Statistics, 2007). It also includes a massive increase in the use of blood thinners like Statins, particularly amongst the obese, 
which greatly reduce the chances of dying from blood artery and related problems (Mehta et al. 2006). These mortality risks of cardiovascular diseases, strokes, and diabetes have hence indeed been reported to go down: Gregg et al. (2005) find that the risks from cardiovascular diseases have gone down over time. The decrease has been quite spectacular: Reis et al. (2007) report a dramatic decrease in the death rate from heart disease for people over 65 since the early 1970s. Whilst in 1975 the death rate from heart disease was approximately 2,450 per 100,000 , this rate was 1,400 in $2005 .{ }^{12}$ Finally, Buchwald et al. (2004) shows that bariatric surgery, which has become more common, has substantially improved the health of morbidly obese people. Diabetes, for example, was complete resolved in almost 77 percent of the patients who underwent the surgery.

\section{Prevention effects of more medical attention}

A secondary effect of the medicalization of obesity is that it has inadvertently protected the obese from selected diseases. Again, the widespread use of blood thinners such as Statins will have protected the obese from strokes which, as we can see from Table 2, the obese have less and, as we can see from Table 5, they die of less often. It furthermore seems likely that regular medical check-ups might well also have lead to the earlier discovery of chronic lung disease such that it can still be effectively treated. This is consistent with the finding of Table 2 that the obese have a higher rate of having been diagnosed with chronic lung disease but why they are significantly less likely to die of it, as witnessed by Table 5. Both these causal mechanisms are in line with Figure 3 and suggest that money matters more than previously thought to matter in terms of health benefits (see Jones 2007 or Frijters et al. 2005).

\section{But how much does it cost and who should pay?}

What have been the costs of the health benefits arising from the medicalization of obesity and who pays? If we combine the prevalence of obesity in groups above age 40 in our sample with the population structure of the US in July 2007, ${ }^{13}$ then it turns out there are approximately $34,650,000$ people older than age 40 who are considered obese. Using our

\footnotetext{
${ }^{12}$ Zizza et al (2004) finds that the obese have longer lengths of hospital stays.

${ }^{13}$ The percentage of obese people in the HRS data is 29 percent for those aged 40-50, 28 percent for those 50-60, 27 percent for those 60-70, and 19 percent for those 70-80, and 11 percent for people 80 years old and over.
} 
estimate of extra expenditure for the obese (on average US\$1,930 for the ten-year period 1992-2002), obese people cost around 66.7 billion dollars per year in health expenditure in 2002 dollars, which is somewhat of an underestimate if we consider that this figure neglects the obese who are younger than 40. It turns out that this back-the-envelope estimate is close to the 52.4 billion figure found by Finkelstein et al. (2003) who use data from the National Health Interview Survey and National Health Accounts which is richer in medical expenditure information than our data. If we then assume that the costs per obese individual increase linearly in the next 10 years as they have in the last 10 years, and if we assume the total number of obese people remains unchanged, the costs would reach 86.6 billion in 2002 dollars in the next 10 years, or around 1 percent of GDP. This estimate is conservative since it ignores the health costs of the overweight.

Who pays this bill? Finkelstein et al. (2003) point out that half of the health cost of obesity is paid by Medicare and Medicaid, 35 percent by Private insurers (who are not allowed to differentiate fees on the basis of obesity), and 15 percent is out-of-pocket. This constitutes a large externality on the public purse and even on other users of private insurance. From a classic economic point of view, considering obesity as the outcome of individual choices, the textbook economic reaction to such a large externality is to transfer the costs to those generating the externality.

There are three potential ways in which the health bill that is currently borne by the whole community can be laid at the door of the obese. The first is a Pigovian 'obesity tax' of around 2000 dollars per obese individual. The disadvantage of such a tax is that one would have to continuously update its level and would require fairly invasive monitoring. The second is to have transferable 'obesity rights' bought under an auctioned licensing system. Though such auctioned property rights might be optimal in the case of a few polluters, it has to be doubted whether it could work effectively if about 40 million individuals were involved. The final and probably easiest way to transfer the externality onto the obese themselves is to let both Private and Public health insurers differentiate their fees and the access to various medical procedures by obesity. These textbook economic reactions to the externality created by the obese are welfare-superior to a fast- 
food tax, which penalizes not only the obese but also the non-obese and which can furthermore be expected to lead to costly monitoring and label-fudging.

\section{Conclusion: a resolution of the puzzle?}

In this paper we started out with the paradox that the obese suffer from more diseases and yet die later than the non-obese. Using the HRS which follows roughly 30,000 individuals for up to 14 years in the period 1992-2006, this paradox was shown to be robust to the inclusion of smoking, socio-economic variables, medical history, long-run effects of obesity, and the thinning that takes place over time.

The overall story that emerged is that obesity has ceased being a killer for three distinct reasons. For one, there is overwhelming literature evidence that the diseases that the obese used to die of are simply less threatening than they used to be. Medical treatments like bypasses and blood thinners have effectively reduced the mortality risks associated with obesity. Secondly, within our dataset obesity seems to protect one against the likelihood of taking up smoking to the tune of being 2.1 percent less likely to be a smoker this period if one was obese the last period. Lastly, obese individuals seem to be able to survive strokes and chronic lung diseases more readily than the non-obese, probably because they already receive medication preventing strokes and due to the more regular check-ups allowing early detection of chronic lung disease. This points to an important additional avenue for health spending to have improved the life expectancy of Americans.

All in all, our findings mean that we should not expect the obesity epidemic to seriously reduce life expectancies and that there is no clear negative mortality effect from our modern way of life via the increase in obesity. None of this is to say that obesity is a desirable condition because the obese still have much higher health costs and notably suffer from a variety of ailments and discomforts that are costly to combat. Indeed, the fact that they live longer merely increases the costs of obesity! Nevertheless, it appears that obesity is not as dangerous as once thought and that the closer medical scrutiny 
enjoyed by the obese is having unexpected benefits. The other side of this coin is that the health costs of obesity are currently around 70 billion a year, of which nearly $85 \%$ is borne by the community rather than by the obese themselves. The logical economic reaction to this is to tax the obese for generating the externality (around 2000 dollars per obese per year), preferably in the form of allowing for fee differentiation on the basis of obesity. 


\section{References}

American Heart Association, 2006. Heart disease and stroke statistics-206 Update: A report from the American heart Association Statistics Committee and Stroke Statistics Subcommittee. Circulation: Journal of the American Heart Association.

Arday, D.R., 1995. Cigarette smoking and self-reported health problems among U.S. high school seniors, 1982-1989. American Journal of Health Promotion 10, 111-116.

Bender, R., Zeeb, H., Schwarz, M., Jockel, K. H., Berger, M., 2006. Causes of death in obesity: Relevant increase in cardiovascular but not in all-cancer mortality. Journal of Clinical Epidemiology 59(10), 1064-1071.

Buchwald, H., Avidor, Y, Braunwald, E., Jensen, M., Pories, W., Fahrbach, K., Schoelles, K., 2004. Bariatric Surgery: A Systematic Review and Meta-analysis. Journal of the American Medical Association 292(14), 1724-1737.

Calle, E.E., Thun, M., Petrelli, J.M., Rodriguez, C., Heath, C.W., 1999. Body-Mass Index and mortality in a prospective cohort of U.S. adults. Journal of the American Medical Association 341(15), 1097-1105.

Calle, E.E., L.R. Teras, Thun, M.J., 2005. Obesity and mortality, New England Journal of Medicine 353(20), 2197-2199.

Couzin, J., 2005. A Heavyweight Battle Over CDC's Obesity Forecasts. Science 308, 770-771.

Cutler, D., Glaeser, E., 2005. What explains differences in smoking, drinking, and other health-related behaviours? Working Paper, Harvard University.

Flegal, K. M., B. I. Graubard, Williamson, D.F., Gail, M.H., 2005. Excess deaths associated with underweight, overweight, and obesity. Journal of the American Medical Association 293(15), 1861-1867.

Finkelstein, E. A., I. C. Fiebelkorn, Wang, G., 2003. National medical spending attributable to overweight and obesity: How much, and who's paying? Health Affairs W3, 219-226.

Flegal. K., 2007. The effects of changes in smoking prevalence on obesity prevalence in the United States. American Journal of Public Health 97(8),1510-1514.

Flegal, K. M., B. I. Graubard, Williamson, D.F., Gail., M.H., 2007. Cause-specific excess Deaths associated with underweight, overweight, and obesity. Journal of the American Medical Association 298(17), 2028-2037. 
Flegal, K., Williamson, D., Pamuk, E., Rosenberg, H.M., 2004. Estimating Deaths Attributable to Obesity in the United States. American Journal of Public Health 94(9), 1486-1489.

Fontaine, K.R., Redden, D.T., Wang C., Westfall, A.O, Allison, D.B., 2003. Years of life lost due to obesity. Journal of the American Medical Association 289:187-193.

Frijters, P., Shields, M.A., Haisken-DeNew, J.P., 2005. The effect of income on health: evidence from a large scale natural experiment. Journal of Health Economics 24, 9971017.

Gregg, E. W., Cheng, Y. J., Cadwell, B.L, Imperatore, G., Williams, D.E., Flegal, K.M., Narayan, K.M., Williamson, D.F. , 2005. Secular Trends in Cardiovascular Disease Risk Factors According to Body Mass Index in US Adults. Journal of the American Medical Association 293(15), 1868-1874.

Harvard School of Public Health, 2005. Weighting the evidence: Symposium on overweight, obesity and mortality. http://www.hsph.harvard.edu/weighing_the_evidence/ (accessed July18, 2005).

Johnson, P.B., Richter, L., 2002. The relationship between smoking, drinking, and adolescents' self-perceived health and frequency of hospitalization: analyses from the 1997 National Household Survey on Drug Abuse. Journal of Adolescent Health 30 (3), 175-183.

Jones, A.M. (2007, ed). Elgar Companion to Health Economics. Edward Elgar. Forthcoming

Kingsland, J., 2005. A pastry a day... . New Scientist 188, 39-41.

Kolata, G., 2005. Some extra heft may be helpful, new study says. The New York Times, April 20. New York.

Kolata, G., 2005. Study tying longer life to extra pounds draws fire. The New York Times, May 27. New York.

Kolata, G., 2007. Overweight people found less likely to die from some diseases. The New York Times. New York.

Kung, H., Hoyert, D.L., Xu, J., Murphy, S.L, 2005. Deaths: Final data for 2005. National Vital Statistics Reports 56(10).

Lawlor, D. A., Hart, C.L., Hole, D.J., Smith, G.D., 2006. Reverse causality and confounding and the associations of overweight and obesity with mortality. Obesity 14(12), 2294-2304. 
Livingston, E.H., 2007. Obesity, Mortality, and Bariatric Surgery Death Rates. Journal of the American Medical Association 298(20), 2406-2408.

Manson, J.E., Stampfer, M.J., Hennekens, C.H., Willett, W.C., 1987. Body weight and longevity: A reassessment. Journal of the American Medical Association 257, 353-358.

Manson, J.E., Willett, W.C., M.J. Stampfer, Colditz, G.A., Hunter, D.J., Hankinson, S.E., Hennekens, C.H., Speizer, F., 1995. Body weight and mortality among women. The New England Journal of Medicine 333(11), 677-685.

McGee, D., 2005. Body Mass index and Mortality: A Meta-Analysis based on personlevel data from twenty-six observational studies. Annals of Epidemiology 15(2), 87-97.

Mehta, J.L, Bursac, Z., Hauer-Jensen, M., Fort, C., Fink, L.M., 2006. Comparison of mortality rates in statin users versus nonstatin users in a United States veteran population. The American Journal of Cardiology 98(7), 923-928.

National Center for Health Statistics, 2007. Health, United States, 2007 with chartbook on trends on the health of Americans. Hyattsville, MD.

Olshansky, S. J., Passaro, D.J., Hershow, R., Layden, J., Carnes, B., Brody, J., Hayflick, L., Butler, R., Allison, D., Ludwig, D., 2005. A Potential Decline in Life Expectancy in the United States in the 21st Century. The New England Journal of Medicine 352(11), 1138-1145.

Pamuk, E., Makuc, D., Heck, K., Reuben, C., Lochner, K. Socioeconomic Status and Health Chartbook. Health, United States, 1998. Hyattsville, Maryland, National Center for Health Statistics. 1998.

Ries L., Melbert D., Krapcho M., Stinchcomb D.G., Howlader N., Horner M.J., Mariotto A., Miller B.A., Feuer E.J., Altekruse S.F., Lewis D.R., Clegg L., Eisner M.P., Reichman M., Edwards BK (eds). SEER Cancer Statistics Review, 1975-2005, National Cancer Institute. Bethesda, MD, http://seer.cancer.gov/csr/1975_2005/, based on November 2007 SEER data submission, posted to the SEER web site, 2008.

Sloan, F., Osterman, J., Conover, C., Taylor, D., Picone, G., 2004. The price of smoking. MIT press.

Sturm, R., 2002. The effects of obesity, smoking, and drinking on medical problems and costs. Health Affairs, 245-253.

World Health Organization, 2000. Obesity: preventing and managing the global epidemic. Report of a WHO Consultation. WHO Technical Report Series 894. Geneva.

Zizza, C., Herring, A., Stevens, J., Popkin, B., 2004. Length of Hospital Stays Among Obese Individuals. American Journal of Public Health 94(9), 1587-1591. 


\section{Tables and Figures}

Table 1: Probability of Dying at Time $t$ Given Obesity in Previous Periods

\begin{tabular}{cccccr}
\hline Period & Non-obese & Obese & $\begin{array}{c}\text { Difference in probability } \\
\text { (Obese - non-obese) }\end{array}$ & $\begin{array}{c}\text { Person-year } \\
\text { observations }\end{array}$ \\
\hline$t-1$ & .0581 & .0306 & -.0275 & .0000 & 145993 \\
$t-2$ & .0594 & .0379 & -.0215 & .0000 & 119733 \\
$t-3$ & .0585 & .0410 & -.0175 & .0000 & 94243 \\
$t-4$ & .0557 & .0419 & -.0138 & .0000 & 72968 \\
$t-5$ & .0490 & .0397 & -.0093 & .0000 & 53085 \\
$t-6$ & .0406 & .0349 & -.0057 & .0194 & 34611 \\
\hline \hline
\end{tabular}

Source: Authors calculations based on RAND-HRS Version H.

Table 2: The Probability of Having Various other Health Problems for the Obese and the Non-Obese

\begin{tabular}{|c|c|c|c|c|c|}
\hline Health condition & Non-obese & Obese & $\begin{array}{c}\text { Difference in probability } \\
\text { (Obese- non-obese) }\end{array}$ & p-value & $\begin{array}{l}\text { Person-year } \\
\text { observations }\end{array}$ \\
\hline 1. High blood pressure or hypertension & .4394 & .6186 & .1792 & .0000 & 139885 \\
\hline 2. Diabetes or high blood sugar & .1161 & .2578 & .1417 & .0000 & 144075 \\
\hline $\begin{array}{l}\text { 3. Cancer or a malignant tumor of any kind (except } \\
\text { skin cancer) }\end{array}$ & .1138 & .1021 & -.0117 & .0000 & 144965 \\
\hline $\begin{array}{l}\text { 4. Chronic lung disease such as chronic bronchitis } \\
\text { or emphysema (except asthma) }\end{array}$ & .0878 & .1000 & .0122 & .0000 & 144054 \\
\hline $\begin{array}{l}\text { 5. Heart attack, coronary heart disease, angina, } \\
\text { congestive heart failure, or other }\end{array}$ & .2131 & .2323 & .0192 & .0000 & 144366 \\
\hline 6. Stroke or transient ischemic attack (TIA) & .0621 & .0554 & -.0067 & .0000 & 144424 \\
\hline 7. Emotional, nervous, or psychiatric problems & .1310 & .1683 & .0374 & .0000 & 143126 \\
\hline 8. Arthritis or rheumatism & .4812 & .6104 & .1292 & .0000 & 139908 \\
\hline 9. Smoking & .2001 & .1418 & -.0583 & .0000 & 130942 \\
\hline
\end{tabular}

Source: Authors calculations based on RAND-HRS Version H. 
Table 3a: Probability of Dying at Time $t$ given Obesity in Previous Periods

\begin{tabular}{|c|c|c|c|c|c|}
\hline & Model 1 & Model 2 & Model 3 & Model 4 & BMI Model $^{(\mathrm{a})}$ \\
\hline Obese $\mathrm{t}-1$ & $\begin{array}{l}-114 \\
(7.14)\end{array}$ & & & & \\
\hline Obese $\mathrm{t}-2$ & & $\begin{array}{l}-.038 \\
(2.20)\end{array}$ & & & \\
\hline Obese $\mathrm{t}-3$ & & & $\begin{array}{c}-.011 \\
(.57)\end{array}$ & & \\
\hline Change obesity ( $\mathrm{t}-2$ to $\mathrm{t}-1$ ) & & & & $\begin{array}{l}.258 \\
(5.58)\end{array}$ & $\begin{array}{c}.075 \\
(15.49)\end{array}$ \\
\hline Change obesity ( $\mathrm{t}-3$ to $\mathrm{t}-2$ ) & & & & $\begin{array}{l}.242 \\
(4.48)\end{array}$ & $\begin{array}{c}.074 \\
(12.37)\end{array}$ \\
\hline Change obesity ( $\mathrm{t}-4$ to $\mathrm{t}-3$ ) & & & & $\begin{array}{l}.228 \\
(4.04)\end{array}$ & $\begin{array}{l}.059 \\
(9.29)\end{array}$ \\
\hline Change obesity (t-5 to t- 4 ) & & & & $\begin{array}{l}.178 \\
(3.37)\end{array}$ & $\begin{array}{l}.050 \\
(8.33)\end{array}$ \\
\hline Obese $\mathrm{t}-5$ & & & & $\begin{array}{l}-.039 \\
(1.23)\end{array}$ & $\begin{array}{l}-.008 \\
(3.39)\end{array}$ \\
\hline Age & $\begin{array}{c}.042 \\
(73.51)\end{array}$ & $\begin{array}{c}.044 \\
(67.21)\end{array}$ & $\begin{array}{c}.044 \\
(57.98)\end{array}$ & $\begin{array}{c}.040 \\
(36.42)\end{array}$ & $\begin{array}{c}.036 \\
(31.46)\end{array}$ \\
\hline Constant & $\begin{array}{l}-4.568 \\
(106.55)\end{array}$ & $\begin{array}{l}-4.718 \\
(95.63)\end{array}$ & $\begin{array}{l}-4.744 \\
(82.58)\end{array}$ & $\begin{array}{l}-4.598 \\
(54.25)\end{array}$ & $\begin{array}{l}-4.105 \\
(34.90)\end{array}$ \\
\hline $\begin{array}{l}\text { Person-year obs. } \\
\text { Individuals } \\
\text { Number of deaths }\end{array}$ & $\begin{array}{c}145,991 \\
30,284 \\
7,538 \\
\end{array}$ & $\begin{array}{c}113,224 \\
27,284 \\
6,179 \\
\end{array}$ & $\begin{array}{c}87,181 \\
22,148 \\
4,813 \\
\end{array}$ & $\begin{array}{c}43,311 \\
16,079 \\
2,014 \\
\end{array}$ & $\begin{array}{r}43,311 \\
16,079 \\
2,014 \\
\end{array}$ \\
\hline
\end{tabular}

Notes:

The specification for Models 1 to 3 is $\operatorname{Pr}\left(\right.$ Death $\left._{i t}=1\right)=\Phi\left(\alpha_{j}\right.$ Obese $\left._{i, t-j}+X_{i, t} \beta\right)$ for $j=1,2,3$. In Model 4, we estimate $\operatorname{Pr}\left(\right.$ Death $\left._{i t}=1\right)=\Phi\left(\sum_{j=1}^{4} \gamma_{j}\right.$ DObese $_{i, t-j}+\gamma_{5}$ Obese $\left._{i, t-5}+X_{i, t} \beta\right)$.

(a) The model is: $\operatorname{Pr}\left(\right.$ Death $\left._{i t}=1\right)=\Phi\left(\sum_{j=1}^{4} \gamma_{j} \Delta B M I_{i, t-j}+\gamma_{5} B M I_{i, t-5}+X_{i, t} \beta\right)$

Source: Authors calculations based on RAND-HRS Version H. Absolute value of Z-statistics in parentheses. 
Table 3b: Probability of Dying at Time $t$ given Obesity and smoking Histories

\begin{tabular}{|c|c|c|c|c|c|}
\hline & Model 1 & Model 2 & Model 3 & Model 4 & BMI Model $^{\text {(a) }}$ \\
\hline Obese t-1 & $\begin{array}{l}-.090 \\
(5.60)\end{array}$ & & & & \\
\hline Obese $\mathrm{t}-2$ & & $\begin{array}{c}-.006 \\
(.32)\end{array}$ & & & \\
\hline Obese $\mathrm{t}-3$ & & & $\begin{array}{l}.026 \\
(1.35)\end{array}$ & & \\
\hline Change obesity (t-2 to t-1) & & & & $\begin{array}{l}.275 \\
(5.82)\end{array}$ & $\begin{array}{c}.076 \\
(15.48)\end{array}$ \\
\hline Change obesity (t-3 to t-2) & & & & $\begin{array}{l}.240 \\
(4.34)\end{array}$ & $\begin{array}{c}.073 \\
(12.00)\end{array}$ \\
\hline Change obesity (t-4 to $t-3$ ) & & & & $\begin{array}{l}.217 \\
(3.74)\end{array}$ & $\begin{array}{l}.059 \\
(9.01)\end{array}$ \\
\hline Change obesity (t-5 to t-4) & & & & $\begin{array}{l}.153 \\
(2.84)\end{array}$ & $\begin{array}{c}.048 \\
(7.86)\end{array}$ \\
\hline Obese $t-5$ & & & & $\begin{array}{l}.004 \\
(.13)\end{array}$ & $\begin{array}{l}-.004 \\
(1.61)\end{array}$ \\
\hline Smoking t-1 & $\begin{array}{c}.301 \\
(17.95)\end{array}$ & & & & \\
\hline Smoking t-2 & & $\begin{array}{c}.365 \\
(20.06)\end{array}$ & & & \\
\hline Smoking t-3 & & & $\begin{array}{c}.400 \\
(19.94)\end{array}$ & & \\
\hline Change smoking ( $\mathrm{t}-2$ to $\mathrm{t}-1)$ & & & & $\begin{array}{l}.146 \\
(2.43)\end{array}$ & $\begin{array}{l}.184 \\
(3.03)\end{array}$ \\
\hline Change smoking ( $\mathrm{t}-3$ to $\mathrm{t}-2$ ) & & & & $\begin{array}{l}.142 \\
(2.15)\end{array}$ & $\begin{array}{l}.210 \\
(3.13)\end{array}$ \\
\hline Change smoking ( $\mathrm{t}-4$ to $\mathrm{t}-3$ ) & & & & $\begin{array}{c}-.026 \\
(.38)\end{array}$ & $\begin{array}{l}.043 \\
(.63)\end{array}$ \\
\hline Change smoking (t-5 to $t-4)$ & & & & $\begin{array}{l}-.168 \\
(2.57)\end{array}$ & $\begin{array}{l}-.106 \\
(1.58)\end{array}$ \\
\hline Smoking t-5 & & & & $\begin{array}{c}.388 \\
(11.01)\end{array}$ & $\begin{array}{l}.353 \\
(9.84)\end{array}$ \\
\hline Age & $\begin{array}{c}.045 \\
(74.74)\end{array}$ & $\begin{array}{c}.048 \\
(69.06)\end{array}$ & $\begin{array}{c}.048 \\
(60.03)\end{array}$ & $\begin{array}{c}.045 \\
(37.76)\end{array}$ & $\begin{array}{c}.041 \\
(32.81)\end{array}$ \\
\hline Constant & $\begin{array}{l}-4.824 \\
(105.14)\end{array}$ & $\begin{array}{l}-5.055 \\
(95.12)\end{array}$ & $\begin{array}{l}-5.132 \\
(82.62)\end{array}$ & $\begin{array}{l}-5.033 \\
(53.75)\end{array}$ & $\begin{array}{l}-4.634 \\
(35.85)\end{array}$ \\
\hline Person-year obs. & 145,409 & 112,806 & 86,891 & 42,358 & 42,358 \\
\hline Individuals & 30,279 & 27,280 & 22,147 & 15,922 & 15,922 \\
\hline Number of deaths & 7,508 & 6,160 & 4,794 & 1,967 & 1,967 \\
\hline
\end{tabular}

Notes: The specification for Models 1 to 3 is $\operatorname{Pr}\left(\right.$ Death $\left._{i t}=1\right)=\Phi\left(\alpha_{j}\right.$ Obese $_{i, t-j}+\theta_{j}$ Smoke $\left._{i, t-j}+X_{i, t} \beta\right)$ for $j=1,2,3$. In

Model 4, we estimate $\operatorname{Pr}\left(\right.$ Death $\left._{i t}=1\right)=\Phi\left(\sum_{j=1}^{5} \gamma_{j}\right.$ Obese $_{i, t-j}+\sum_{j=1}^{5} \rho_{j}$ Smoke $\left._{i, t-j}+X_{i, t} \beta\right)$.

(a) The model is $\operatorname{Pr}\left(\right.$ Death $\left._{i t}=1\right)=\Phi\left(\sum_{j=1}^{4} \gamma_{j} \Delta B M I_{i, t-j}+\gamma_{5} B M I_{i, t-5}+\sum_{j=1}^{4} \rho_{j} \Delta\right.$ Smoke $_{i, t-j}+\rho_{5}$ Smoke $\left._{i, t-5}+X_{i, t} \beta\right)$

Source: Authors calculations based on RAND-HRS Version H. Absolute value of Z-statistics in parentheses. 
Table 4: Relationship between Smoking and Obesity/BMI

\begin{tabular}{|c|c|c|c|c|c|c|}
\hline & \multicolumn{3}{|c|}{ Obesity/BMI Equation } & \multirow{2}{*}{\multicolumn{3}{|c|}{ Probit for Smoking }} \\
\hline & \multicolumn{2}{|c|}{ Level equations $^{\text {(a) }}$} & \multirow{2}{*}{$\begin{array}{c}\text { Change }^{(\mathrm{b})} \\
\text { BMI } \\
(\mathrm{OLS})\end{array}$} & & & \\
\hline & $\begin{array}{c}\text { Obese } \\
\text { (probit) }\end{array}$ & $\begin{array}{c}\text { BMI } \\
(\mathrm{OLS}) \\
\end{array}$ & & $\begin{array}{c}\text { Using obese as } \\
\text { regressor }^{(\mathrm{c})}\end{array}$ & $\begin{array}{l}\text { Using BMI as } \\
\text { regressor }^{(\mathrm{c})}\end{array}$ & $\begin{array}{c}\text { Using BMI as } \\
\text { regressor }^{(\mathrm{d})}\end{array}$ \\
\hline Obese t-1 & $\begin{array}{l}1.491 \\
(56.16)\end{array}$ & & & $\begin{array}{c}-.025 \\
(.43)\end{array}$ & & \\
\hline Obese $\mathrm{t}-2$ & $\begin{array}{c}.759 \\
(25.04)\end{array}$ & & & $\begin{array}{l}-.085 \\
(1.31)\end{array}$ & & \\
\hline Obese $\mathrm{t}-3$ & $\begin{array}{c}.479 \\
(14.95)\end{array}$ & & & $\begin{array}{c}-.055 \\
(.84)\end{array}$ & & \\
\hline Obese $\mathrm{t}-4$ & $\begin{array}{c}.479 \\
(15.99)\end{array}$ & & & $\begin{array}{c}.118 \\
(1.99)\end{array}$ & & \\
\hline BMI t-1 & & $\begin{array}{c}.619 \\
(110.12)\end{array}$ & & & $\begin{array}{l}-.021 \\
(2.91)\end{array}$ & $\begin{array}{l}-.010 \\
(6.23)\end{array}$ \\
\hline BMI t-2 & & $\begin{array}{c}.194 \\
(28.77)\end{array}$ & & & $\begin{array}{l}-.010 \\
(1.14)\end{array}$ & \\
\hline BMI t-3 & & $\begin{array}{c}.092 \\
(13.30)\end{array}$ & & & $\begin{array}{l}.006 \\
(.62)\end{array}$ & \\
\hline BMI t-4 & & $\begin{array}{c}.069 \\
(11.81)\end{array}$ & & & $\begin{array}{l}.021 \\
(2.68)\end{array}$ & \\
\hline Smoking t-1 & $\begin{array}{l}-.295 \\
(5.64)\end{array}$ & $\begin{array}{l}-.380 \\
(6.26)\end{array}$ & $\begin{array}{l}-.423 \\
(11.96)\end{array}$ & $\begin{array}{l}1.758 \\
(45.50)\end{array}$ & $\begin{array}{l}1.741 \\
(44.87)\end{array}$ & $\begin{array}{c}3.090 \\
(204.16)\end{array}$ \\
\hline Smoking t-2 & $\begin{array}{c}.066 \\
(1.12)\end{array}$ & $\begin{array}{c}.097 \\
(1.43)\end{array}$ & $\begin{array}{c}.407 \\
(11.95)\end{array}$ & $\begin{array}{c}.828 \\
(18.10)\end{array}$ & $\begin{array}{c}.823 \\
(17.93)\end{array}$ & \\
\hline Smoking t-3 & $\begin{array}{l}.120 \\
(2.03)\end{array}$ & $\begin{array}{l}.020 \\
(.30)\end{array}$ & & $\begin{array}{c}.525 \\
(10.59)\end{array}$ & $\begin{array}{c}.531 \\
(10.69)\end{array}$ & \\
\hline Smoking t-4 & $\begin{array}{l}.029 \\
(.57)\end{array}$ & $\begin{array}{l}.131 \\
(2.33)\end{array}$ & & $\begin{array}{c}.553 \\
(11.81)\end{array}$ & $\begin{array}{c}.560 \\
(11.92)\end{array}$ & \\
\hline Age & $\begin{array}{l}-.020 \\
(17.21)\end{array}$ & $\begin{array}{l}-.036 \\
(30.47)\end{array}$ & & $\begin{array}{l}-.009 \\
(5.06)\end{array}$ & $\begin{array}{l}-.010 \\
(5.69)\end{array}$ & \\
\hline Constant & $\begin{array}{l}-.371 \\
(4.64)\end{array}$ & $\begin{array}{l}3.310 \\
(29.78)\end{array}$ & $\begin{array}{c}-.001 \\
(.14)\end{array}$ & $\begin{array}{r}-1.883 \\
(14.78)\end{array}$ & $\begin{array}{r}-1.680 \\
(10.41)\end{array}$ & $\begin{array}{r}-1.880 \\
(44.43)\end{array}$ \\
\hline Sum obese & $\begin{array}{c}3.208 \\
(129.35)\end{array}$ & $\begin{array}{c}.974 \\
(445.09)\end{array}$ & & $\begin{array}{l}-.047 \\
(1.17)\end{array}$ & $\begin{array}{l}-.005 \\
(1.50)\end{array}$ & \\
\hline Sum smoking & $\begin{array}{l}-.081 \\
(2.72)\end{array}$ & $\begin{array}{l}-.132 \\
(4.09)\end{array}$ & $\begin{array}{c}-.017 \\
(.86)\end{array}$ & $\begin{array}{c}3.663 \\
(106.95)\end{array}$ & $\begin{array}{c}3.656 \\
(106.18)\end{array}$ & \\
\hline Marginal effect of sum Smoking ${ }^{(\mathrm{e})}$ & $\begin{array}{l}-.011 \\
(2.72)\end{array}$ & & & & & \\
\hline Person-year observations & 42107 & 42107 & 108817 & 42335 & 42335 & 109796 \\
\hline
\end{tabular}

Notes:

(a) The first is a Probit model of being obese: $\operatorname{Pr}\left(\right.$ Obese $\left._{i t}=1\right)=\Phi\left(\sum_{j=1}^{4} \alpha_{j}\right.$ Obese $_{i, t-j}+\sum_{j=1}^{4} \theta_{j}$ Smoke $\left._{i, t-j}\right)$ and the second one is an ordinary least square regression where the dependent variable is BMI:

$$
B M I_{i t}=\sum_{j=1}^{4} \alpha_{j} B M I_{i, t-j}+\sum_{j=1}^{4} \theta_{j} \text { Smoke }_{i, t-j}+\varepsilon_{i t} .
$$

(b) In this specification we estimate: $\Delta B M I_{i t}=\delta_{1}$ Smoke $_{i, t}+\delta_{2}$ Smoke $_{i, t-1}+\varepsilon_{i t}$.

(c) The specification in this case is: $\operatorname{Pr}\left(\right.$ Smoke $\left._{i t}=1\right)=\Phi\left(\sum_{j=1}^{4} \gamma_{j}\right.$ Obese $_{i, t-j}+\sum_{j=1}^{4} \rho_{j}$ Smoke $\left._{i, t-j}\right)$. We also estimate a model in which BMI is used instead of obesity.

(d) In this case the specification is $\operatorname{Pr}\left(\right.$ Smoke $\left._{i t}=1\right)=\Phi\left(\lambda_{1}\right.$ Obese $_{i, t-1}+\lambda_{2}$ Smoke $\left._{i, t-1}\right)$

(e) Calculated as the sum of the individual marginal effects. Absolute value of Z-statistics in parentheses. 
Figure 1: Average BMI by Age for People who Died before 80 and All People

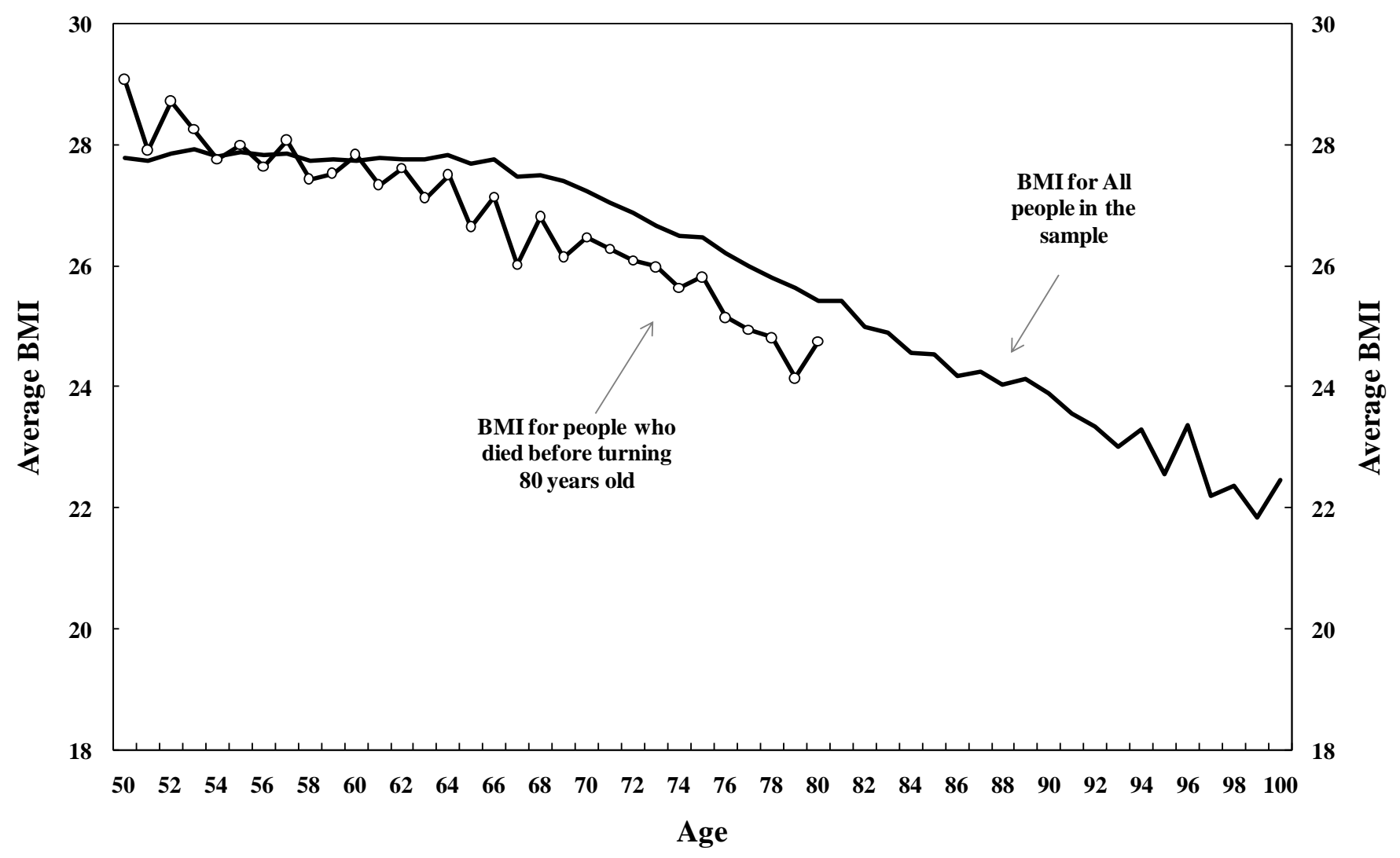

Source: Authors calculations based on RAND-HRS Version H. 
Figure 2: BMI at Previous Periods before Death by Obesity and Illness

High Blood Pressure
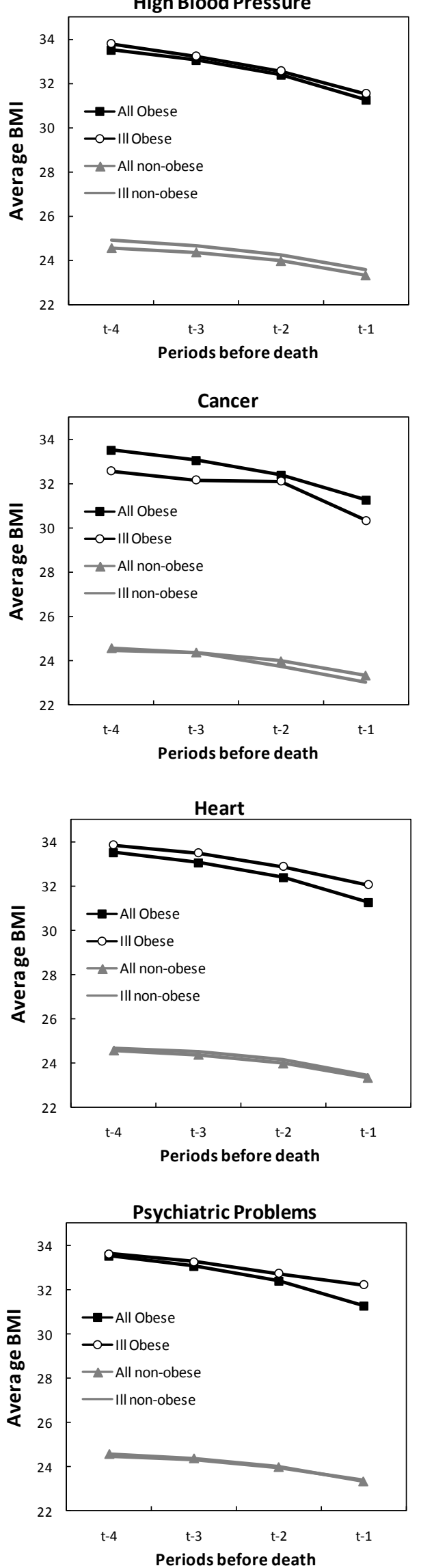
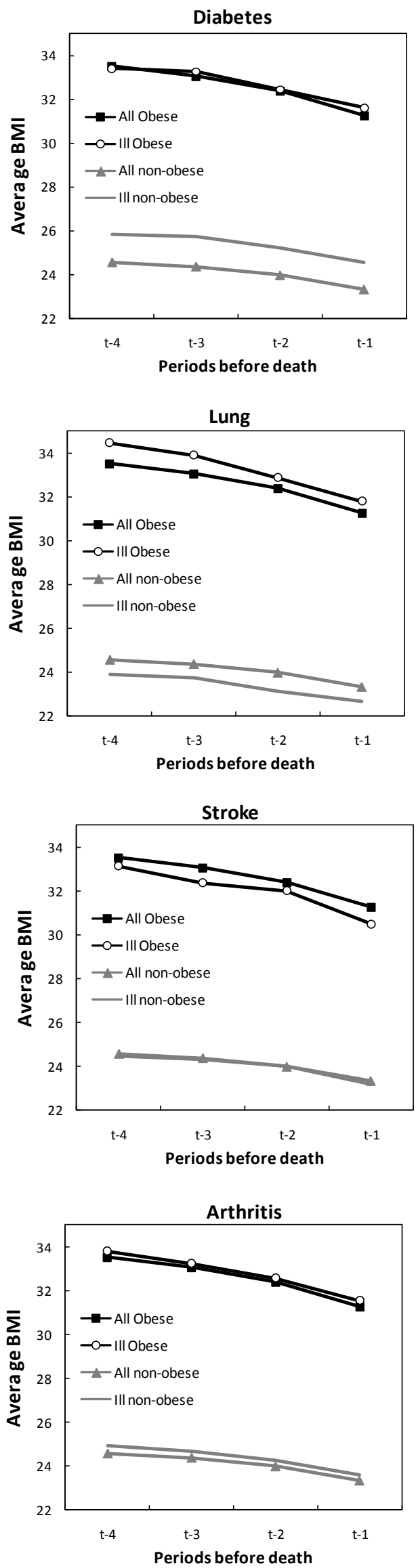
Table 5: Probability of Dying at Time $t$ Given Obesity and Disease in Previous Periods

\begin{tabular}{|c|c|c|c|c|c|c|c|c|}
\hline & \multirow{2}{*}{\multicolumn{2}{|c|}{ No interactions }} & \multicolumn{6}{|c|}{ With interactions between obesity and diseases } \\
\hline & & & \multicolumn{2}{|c|}{ One lag } & \multicolumn{2}{|c|}{ Two lags } & \multicolumn{2}{|c|}{ Four lags } \\
\hline & Coeff. & $|t|$ & Coeff. & $|t|$ & Coeff. & $|t|$ & Coeff. & $|t|$ \\
\hline Age & .051 & $(34.12)$ & .043 & $(62.93)$ & .047 & $(52.57)$ & .051 & $(34.14)$ \\
\hline Obese t-1 & -.302 & $(5.48)$ & -.115 & $(2.76)$ & -.199 & $(2.74)$ & -.310 & $(2.47)$ \\
\hline Obese $\mathrm{t}-2$ & .092 & $(1.50)$ & & & .083 & $(1.31)$ & .097 & $(.75)$ \\
\hline Obese t-3 & .065 & $(1.04)$ & & & & & .105 & $(.85)$ \\
\hline Obese $\mathrm{t}-4$ & .028 & $(.50)$ & & & & & -.004 & $(.04)$ \\
\hline High blood pressure t-1 & -.151 & $(2.64)$ & -.003 & $(.23)$ & -.080 & $(2.15)$ & -.152 & $(2.59)$ \\
\hline High blood pressure t-2 & .019 & $(.25)$ & & & .072 & (1.94) & -.007 & $(.09)$ \\
\hline High blood pressure t-3 & -.025 & $(.30)$ & & & & & -.029 & $(.33)$ \\
\hline High blood pressure t- 4 & .115 & $(1.77)$ & & & & & .138 & $(2.00)$ \\
\hline Diabetes t-1 & .055 & $(.71)$ & .288 & $(15.01)$ & .164 & $(3.32)$ & .078 & $(.94)$ \\
\hline Diabetes $\mathrm{t}-2$ & -.125 & $(1.07)$ & & & .135 & $(2.57)$ & -.101 & $(.82)$ \\
\hline Diabetes $\mathrm{t}-3$ & .127 & $(1.03)$ & & & & & .055 & $(.41)$ \\
\hline Diabetes $\mathrm{t}-4$ & .251 & $(2.71)$ & & & & & .273 & $(2.70)$ \\
\hline Cancer t-1 & .621 & (10.97) & .312 & $(17.11)$ & .669 & $(17.52)$ & .643 & $(10.82)$ \\
\hline Cancer t-2 & -.265 & $(3.00)$ & & & -.483 & $(11.25)$ & -.284 & $(3.09)$ \\
\hline Cancer $\mathrm{t}-3$ & -.082 & $(.80)$ & & & & & -.063 & $(.60)$ \\
\hline Cancer t-4 & -.111 & $(1.32)$ & & & & & -.137 & $(1.55)$ \\
\hline Lung t-1 & .238 & $(3.22)$ & .369 & $(18.04)$ & .395 & $(8.58)$ & .253 & $(3.26)$ \\
\hline Lung $\mathrm{t}-2$ & .090 & $(.86)$ & & & -.035 & $(.69)$ & .116 & $(1.06)$ \\
\hline Lung $\mathrm{t}-3$ & -.066 & $(.55)$ & & & & & -.064 & $(.51)$ \\
\hline Lung t-4 & -.058 & $(.57)$ & & & & & -.026 & $(.24)$ \\
\hline Heart t-1 & .086 & $(1.56)$ & .210 & $(13.23)$ & .171 & $(5.06)$ & .080 & $(1.41)$ \\
\hline Heart t-2 & .084 & $(1.16)$ & & & .030 & $(.86)$ & .030 & $(.39)$ \\
\hline Heart t-3 & -.017 & $(.23)$ & & & & & -.005 & $(.06)$ \\
\hline Heart t-4 & .047 & $(.77)$ & & & & & .071 & $(1.08)$ \\
\hline Stroke t-1 & .283 & $(3.79)$ & .417 & (19.11) & .392 & $(8.47)$ & .328 & $(4.28)$ \\
\hline Stroke t-2 & .202 & $(1.92)$ & & & .019 & $(.37)$ & .206 & $(1.92)$ \\
\hline Stroke $\mathrm{t}-3$ & -.060 & $(.50)$ & & & & & -.130 & $(1.03)$ \\
\hline Stroke t-4 & -.077 & $(.73)$ & & & & & -.049 & $(.43)$ \\
\hline Psychiatric problems t-1 & .129 & $(1.96)$ & .120 & $(6.00)$ & .222 & $(5.40)$ & .108 & $(1.59)$ \\
\hline Psychiatric problems t-2 & .156 & $(1.70)$ & & & -.066 & $(1.43)$ & .148 & $(1.56)$ \\
\hline Psychiatric problems t-3 & .085 & $(.84)$ & & & & & .095 & $(.91)$ \\
\hline Psychiatric problems t-4 & -.217 & $(2.56)$ & & & & & -.188 & $(2.09)$ \\
\hline Arthritis t-1 & .084 & $(1.59)$ & -.077 & $(5.15)$ & .006 & $(.20)$ & .073 & $(1.32)$ \\
\hline Arthritis $\mathrm{t}-2$ & -.201 & $(2.91)$ & & & -.131 & $(4.50)$ & -.158 & $(2.23)$ \\
\hline Arthritis $\mathrm{t}-3$ & .085 & $(1.33)$ & & & & & .090 & $(1.36)$ \\
\hline Arthritis t-4 & -.086 & $(1.93)$ & & & & & -.115 & $(2.45)$ \\
\hline Smoking t-1 & .043 & $(.59)$ & .297 & $(14.59)$ & .041 & $(.94)$ & .038 & $(.51)$ \\
\hline Smoking t-2 & -.036 & $(.45)$ & & & .302 & $(7.28)$ & -.025 & $(.30)$ \\
\hline Smoking t-3 & .156 & $(1.95)$ & & & & & .189 & $(2.25)$ \\
\hline Smoking t-4 & .275 & $(4.13)$ & & & & & .243 & $(3.46)$ \\
\hline Obesity x High blood pressure (t-1) & & & .041 & $(1.04)$ & .009 & $(.13)$ & .024 & $(.22)$ \\
\hline Obesity x High blood pressure (t-2) & & & & & .006 & $(.10)$ & .141 & $(1.18)$ \\
\hline
\end{tabular}




\begin{tabular}{|c|c|c|c|c|c|c|c|}
\hline Obesity x High blood pressure (t-3) & & & & & & -.014 & $(.12)$ \\
\hline Obesity x High blood pressure (t-4) & & & & & & -.092 & $(.90)$ \\
\hline Obesity x Diabetes (t-1) & & -.020 & $(.53)$ & .028 & $(.44)$ & -.070 & $(.66)$ \\
\hline Obesity x Diabetes (t-2) & & & & -.076 & $(1.21)$ & -.078 & $(.63)$ \\
\hline Obesity x Diabetes (t-3) & & & & & & .213 & (1.64) \\
\hline Obesity x Diabetes (t-4) & & & & & & -.071 & $(.60)$ \\
\hline Obesity x Cancer (t-1) & & -.086 & $(1.88)$ & -.175 & $(2.40)$ & -.112 & $(1.00)$ \\
\hline Obesity x Cancer (t-2) & & & & .093 & $(1.21)$ & .174 & $(1.27)$ \\
\hline Obesity x Cancer (t-3) & & & & & & -.242 & $(1.51)$ \\
\hline Obesity x Cancer (t-4) & & & & & & .193 & (1.26) \\
\hline Obesity x Lung (t-1) & & -.125 & $(2.59)$ & -.055 & $(.70)$ & -.069 & $(.52)$ \\
\hline Obesity x Lung (t-2) & & & & -.067 & $(.80)$ & -.150 & $(.92)$ \\
\hline Obesity x Lung (t-3) & & & & & & -.006 & $(.03)$ \\
\hline Obesity x Lung (t-4) & & & & & & -.148 & $(.85)$ \\
\hline Obesity x Heart (t-1) & & .091 & $(2.42)$ & .155 & $(2.60)$ & .007 & $(.07)$ \\
\hline Obesity x Heart (t-2) & & & & .018 & $(.31)$ & .300 & $(2.66)$ \\
\hline Obesity x Heart (t-3) & & & & & & -.068 & $(.59)$ \\
\hline Obesity x Heart (t-4) & & & & & & -.095 & $(.89)$ \\
\hline Obesity x Stroke (t-1) & & -.165 & $(3.00)$ & -.202 & $(2.36)$ & -.359 & $(2.42)$ \\
\hline Obesity x Stroke (t-2) & & & & .007 & $(.08)$ & -.038 & $(.22)$ \\
\hline Obesity x Stroke (t-3) & & & & & & .387 & $(2.06)$ \\
\hline Obesity x Stroke (t-4) & & & & & & -.080 & $(.43)$ \\
\hline Obesity x Psychiatric problems ( $\mathrm{t}-1)$ & & -.035 & $(.77)$ & -.125 & $(1.70)$ & .143 & $(1.18)$ \\
\hline Obesity x Psychiatric problems (t-2) & & & & .077 & $(1.03)$ & .033 & $(.23)$ \\
\hline Obesity x Psychiatric problems ( $\mathrm{t}-3$ ) & & & & & & -.069 & $(.44)$ \\
\hline Obesity x Psychiatric problems (t-4) & & & & & & -.121 & $(.82)$ \\
\hline Obesity x Arthritis (t-1) & & -.038 & $(1.00)$ & -.025 & $(.40)$ & .077 & $(.72)$ \\
\hline Obesity x Arthritis (t-2) & & & & .032 & $(.57)$ & -.291 & $(2.55)$ \\
\hline Obesity x Arthritis (t-3) & & & & & & -.057 & $(.50)$ \\
\hline Obesity x Arthritis (t-4) & & & & & & .210 & $(2.22)$ \\
\hline Obesity x Smoking (t-1) & & .002 & $(.04)$ & -.039 & $(.44)$ & .041 & $(.27)$ \\
\hline Obesity x Smoking (t-2) & & & & -.038 & $(.47)$ & -.082 & $(.51)$ \\
\hline Obesity x Smoking (t-3) & & & & & & -.205 & $(1.34)$ \\
\hline Obesity x Smoking (t-4) & & & & & & .195 & $(1.50)$ \\
\hline Constant & (48.88) & -4.951 & $(94.61)$ & -5.258 & $(76.33)$ & -5.683 & $(48.61)$ \\
\hline Sum of interaction by disease & & & & & & & \\
\hline High blood pressure & & .041 & $(1.04)$ & .015 & $(.27)$ & .058 & $(.61)$ \\
\hline Diabetes & & -.020 & $(.53)$ & -.049 & $(.92)$ & -.006 & $(.06)$ \\
\hline Cancer & & -.086 & $(1.88)$ & -.082 & $(1.28)$ & .014 & $(.12)$ \\
\hline Lung & & -.125 & $(2.59)$ & -.122 & $(1.80)$ & -.373 & $(2.61)$ \\
\hline Heart & & .091 & $(2.42)$ & .173 & $(3.40)$ & .143 & $(1.52)$ \\
\hline Stroke & & -.165 & $(3.00)$ & -.195 & $(2.50)$ & -.090 & $(.60)$ \\
\hline Psychiatric problems & & -.035 & $(.77)$ & -.048 & $(.77)$ & -.015 & (.13) \\
\hline Arthritis & & -.038 & $(1.00)$ & .007 & $(.14)$ & -.061 & $(.64)$ \\
\hline Smoking & \multirow[b]{2}{*}{36817} & .002 & $(.04)$ & -.078 & $(1.02)$ & -.051 & $(.39)$ \\
\hline Person-year observations & & \multicolumn{2}{|c|}{124410} & \multicolumn{2}{|c|}{81864} & \multicolumn{2}{|c|}{36817} \\
\hline
\end{tabular}


Figure 3

\section{Real expenditure on the Obese (age adjusted)}

(1992 dollars)

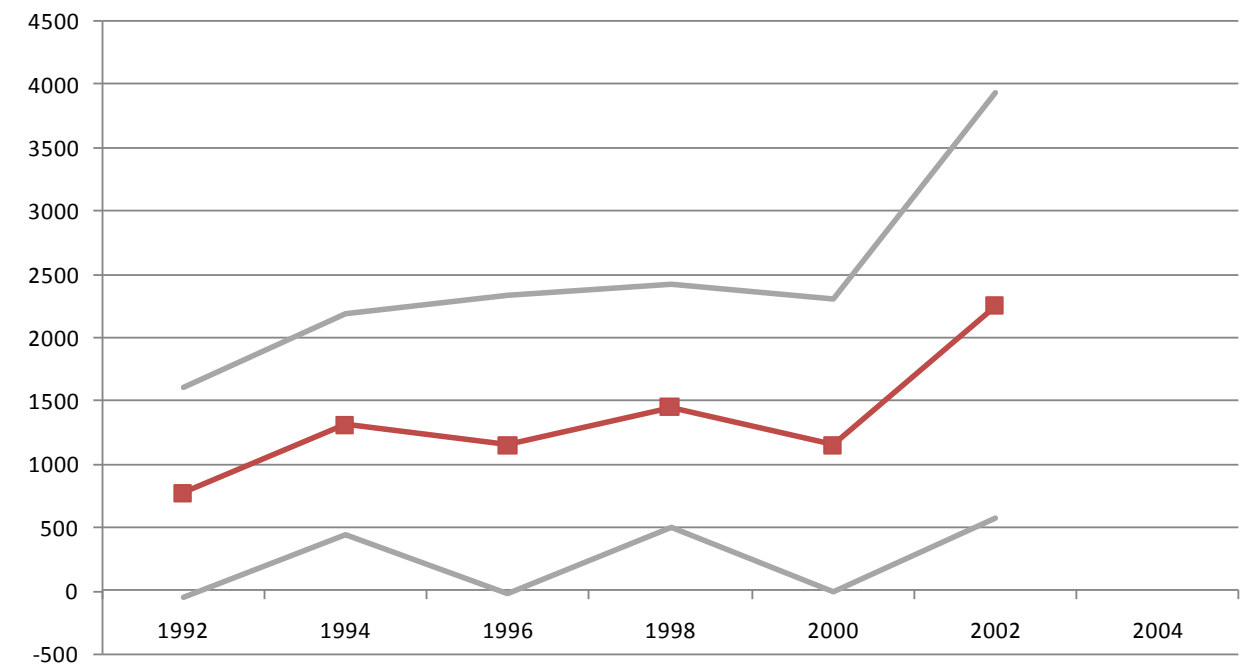

Difference in the Probability of Death

(obese - nonobese; age adjusted)

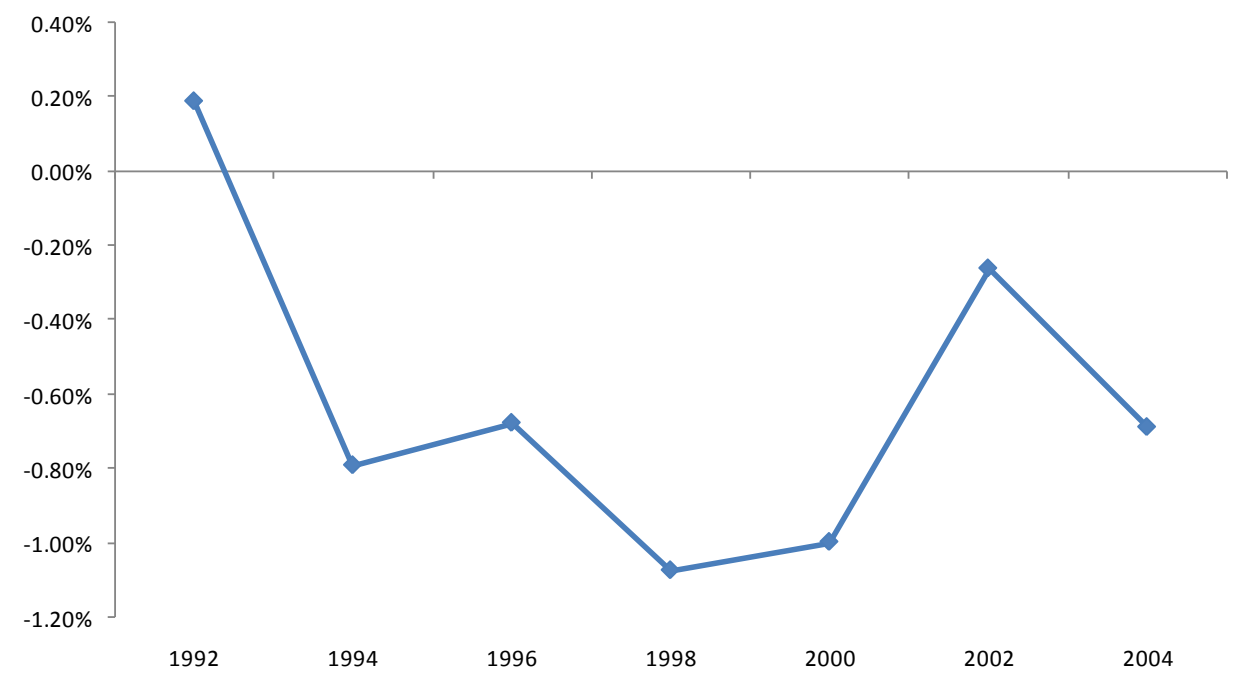

Top Panel: The data for this graph come from running the following model:

Health Expenditure $=\beta_{0}+\beta_{1}$ age $+\beta_{2}$ obese $+\varepsilon$ independently for each year of the survey. The graph shows the coefficient on the obesity dummy variable $\left(\beta_{2}\right)$. Gray lines represent 95 percent level confidence intervals.

Bottom Panel: The information comes from running the Probit model:

$\operatorname{Pr}($ Death Next Period $=1)=\Phi\left(\alpha_{0}+\alpha_{1}\right.$ age $+\alpha_{2}$ Obese $)$, independently for each year. The graph shows the change in probability of death from becoming non-obese in that model:

$\Delta \operatorname{Pr}($ Death Next Period $=1)=\Phi\left(\hat{\alpha}_{0}+\hat{\alpha}_{1}\right.$ age $\left.+\hat{\alpha}_{2}\right)-\Phi\left(\hat{\alpha}_{0}+\hat{\alpha}_{1} a g e\right)$.

Source: Authors calculations based on RAND-HRS Version H. Absolute value of Z-statistics in parentheses. 
Table A1: Relationship between Smoking and Obesity/BMI (controlling for economic determinants)

\begin{tabular}{|c|c|c|c|c|c|c|}
\hline & \multicolumn{3}{|c|}{ Obesity/BMI Equation } & \multirow{2}{*}{\multicolumn{3}{|c|}{ Probit for Smoking }} \\
\hline & \multicolumn{2}{|c|}{ Level equations $^{(a)}$} & \multirow{2}{*}{$\begin{array}{c}\text { Change }^{(\mathrm{b})} \\
\text { BMI } \\
(\mathrm{OLS}) \\
\end{array}$} & & & \\
\hline & $\begin{array}{c}\text { Obese } \\
\text { (probit) }\end{array}$ & $\begin{array}{c}\text { BMI } \\
(\mathrm{OLS}) \\
\end{array}$ & & $\begin{array}{l}\text { Using obese as } \\
\text { regressor }^{(\mathrm{c})}\end{array}$ & $\begin{array}{l}\text { Using BMI as } \\
\text { regressor }^{\text {(c) }}\end{array}$ & $\begin{array}{c}\text { Using BMI as } \\
\text { regressor } \\
\text { (d) }\end{array}$ \\
\hline Obese $\mathrm{t}-1$ & $\begin{array}{l}1.490 \\
(56.27)\end{array}$ & & & $\begin{array}{c}.043 \\
(.76)\end{array}$ & & \\
\hline Obese $\mathrm{t}-2$ & $\begin{array}{c}.751 \\
(24.86)\end{array}$ & & & $\begin{array}{l}-.073 \\
(1.13)\end{array}$ & & \\
\hline Obese $\mathrm{t}-3$ & $\begin{array}{c}.483 \\
(15.13)\end{array}$ & & & $\begin{array}{c}-.050 \\
(.76)\end{array}$ & & \\
\hline Obese $\mathrm{t}-4$ & $\begin{array}{c}.470 \\
(15.73)\end{array}$ & & & $\begin{array}{l}.098 \\
(1.65)\end{array}$ & & \\
\hline BMI t-1 & & $\begin{array}{c}.618 \\
(110.46)\end{array}$ & & & $\begin{array}{l}-.022 \\
(3.07)\end{array}$ & $\begin{array}{l}-.011 \\
(7.04)\end{array}$ \\
\hline BMI t-2 & & $\begin{array}{c}.193 \\
(28.78)\end{array}$ & & & $\begin{array}{c}-.008 \\
(.94)\end{array}$ & \\
\hline BMI t-3 & & $\begin{array}{c}.093 \\
(13.64)\end{array}$ & & & $\begin{array}{l}.004 \\
(.49)\end{array}$ & \\
\hline BMI t-4 & & $\begin{array}{c}.071 \\
(12.17)\end{array}$ & & & $\begin{array}{l}.019 \\
(2.51)\end{array}$ & \\
\hline Smoking t-1 & $\begin{array}{l}-.291 \\
(5.58)\end{array}$ & $\begin{array}{l}-.379 \\
(6.27)\end{array}$ & $\begin{array}{l}-.424 \\
(12.00)\end{array}$ & $\begin{array}{l}1.743 \\
(45.48)\end{array}$ & $\begin{array}{l}1.727 \\
(44.84)\end{array}$ & $\begin{array}{c}3.078 \\
(201.93)\end{array}$ \\
\hline Smoking t-2 & $\begin{array}{l}.061 \\
(1.05)\end{array}$ & $\begin{array}{l}.106 \\
(1.57)\end{array}$ & $\begin{array}{c}.423 \\
(12.43)\end{array}$ & $\begin{array}{c}.828 \\
(18.23)\end{array}$ & $\begin{array}{c}.824 \\
(18.06)\end{array}$ & \\
\hline Smoking t-3 & $\begin{array}{l}.110 \\
(1.88)\end{array}$ & $\begin{array}{l}.013 \\
(.19)\end{array}$ & & $\begin{array}{l}.513 \\
(10.44)\end{array}$ & $\begin{array}{l}.519 \\
(10.52)\end{array}$ & \\
\hline Smoking t-4 & $\begin{array}{l}.026 \\
(.51)\end{array}$ & $\begin{array}{l}.140 \\
(2.50)\end{array}$ & & $\begin{array}{c}.553 \\
(11.88)\end{array}$ & $\begin{array}{c}.559 \\
(11.97)\end{array}$ & \\
\hline Age & $\begin{array}{l}-.020 \\
(17.01)\end{array}$ & $\begin{array}{l}-.035 \\
(29.30)\end{array}$ & & $\begin{array}{l}-.011 \\
(5.91)\end{array}$ & $\begin{array}{l}-.012 \\
(6.51)\end{array}$ & \\
\hline Initial wealth & $\begin{array}{l}.000 \\
(.60)\end{array}$ & $\begin{array}{c}.000 \\
(1.61)\end{array}$ & $\begin{array}{l}.000 \\
(.24)\end{array}$ & $\begin{array}{l}.000 \\
(1.94)\end{array}$ & $\begin{array}{c}.000 \\
(1.94)\end{array}$ & $\begin{array}{l}.000 \\
(4.64)\end{array}$ \\
\hline White & $\begin{array}{l}-.084 \\
(3.33)\end{array}$ & $\begin{array}{l}(.08) \\
(2.69)\end{array}$ & $\begin{array}{l}(.04) \\
(2.07)\end{array}$ & $\begin{array}{l}(.00) \\
(.11)\end{array}$ & $\begin{array}{l}(.00) \\
(.11)\end{array}$ & $\begin{array}{l}-(.03) \\
(1.65)\end{array}$ \\
\hline Hispanic & $\begin{array}{c}-.016 \\
(.44)\end{array}$ & $\begin{array}{l}(.03) \\
(.69)\end{array}$ & $\begin{array}{l}(.11) \\
(4.16)\end{array}$ & $\begin{array}{l}-(.04) \\
(.66)\end{array}$ & $\begin{array}{l}-(.03) \\
(.59)\end{array}$ & $\begin{array}{l}-(.05) \\
(1.57)\end{array}$ \\
\hline Female & $\begin{array}{l}.012 \\
(.55)\end{array}$ & $\begin{array}{l}(.07) \\
(3.01)\end{array}$ & $\begin{array}{l}(.05) \\
(2.97)\end{array}$ & $\begin{array}{l}-(.05) \\
(1.46)\end{array}$ & $\begin{array}{l}-(.05) \\
(1.50)\end{array}$ & $\begin{array}{l}-(.07) \\
(4.00)\end{array}$ \\
\hline Years of education & $\begin{array}{l}-.007 \\
(2.16)\end{array}$ & $\begin{array}{l}(.00) \\
(.60)\end{array}$ & $\begin{array}{l}(.02) \\
(9.44)\end{array}$ & $\begin{array}{l}-(.01) \\
(2.40)\end{array}$ & $\begin{array}{l}-(.01) \\
(2.40)\end{array}$ & $\begin{array}{l}-(.01) \\
(3.03)\end{array}$ \\
\hline Initial income & $\begin{array}{l}.000 \\
(1.46)\end{array}$ & $\begin{array}{l}(.00) \\
(.62)\end{array}$ & $\begin{array}{l}(.00) \\
(5.29)\end{array}$ & $\begin{array}{l}(.00) \\
(1.45)\end{array}$ & $\begin{array}{l}(.00) \\
(1.41)\end{array}$ & $\begin{array}{l}(.00) \\
(.70)\end{array}$ \\
\hline Initial experience & $\begin{array}{c}.001 \\
(1.36)\end{array}$ & $\begin{array}{c}(.00) \\
(2.58)\end{array}$ & $\begin{array}{l}(.00) \\
(.71)\end{array}$ & $\begin{array}{c}(.00) \\
(1.73)\end{array}$ & $\begin{array}{c}(.00) \\
(1.64)\end{array}$ & $\begin{array}{c}(.00) \\
(4.34)\end{array}$ \\
\hline Initial total medical expenditure & $\begin{array}{c}.000 \\
(1.50)\end{array}$ & $\begin{array}{c}(.00) \\
(1.38)\end{array}$ & $\begin{array}{l}(.00) \\
(.89)\end{array}$ & $\begin{array}{l}(.00) \\
(.67)\end{array}$ & $\begin{array}{l}(.00) \\
(.75)\end{array}$ & $\begin{array}{l}(.00) \\
(.15)\end{array}$ \\
\hline Constant & $\begin{array}{l}-.247 \\
(2.51)\end{array}$ & $\begin{array}{l}2.997 \\
(22.52)\end{array}$ & $\begin{array}{l}-.343 \\
(9.64)\end{array}$ & $\begin{array}{c}-1.483 \\
(9.81)\end{array}$ & $\begin{array}{c}-1.241 \\
(6.70)\end{array}$ & $\begin{array}{c}-1.580 \\
(26.33)\end{array}$ \\
\hline Sum obese/BMI coeffs. & $\begin{array}{l}3.944 \\
(93.88)\end{array}$ & $\begin{array}{c}1.169 \\
(162.89)\end{array}$ & & $\begin{array}{l}-.142 \\
(1.78)\end{array}$ & $\begin{array}{r}-.014 \\
(1.56)\end{array}$ & \\
\hline Sum smoking coeffs. & $\begin{array}{c}-.032 \\
(.47)\end{array}$ & $\begin{array}{c}-.013 \\
(.17)\end{array}$ & $\begin{array}{c}-.001 \\
(.04)\end{array}$ & $\begin{array}{l}4.466 \\
(73.61)\end{array}$ & $\begin{array}{l}4.453 \\
(73.00)\end{array}$ & \\
\hline Marginal effect of sum Smoking ${ }^{(\mathrm{e})}$ & $\begin{array}{c}-.014 \\
(.47)\end{array}$ & & & & & \\
\hline Person-year observations & 42385 & 42385 & 108106 & 42615 & 42615 & 109084 \\
\hline
\end{tabular}


Table A2: Probability of Dying at Time $t$ Given Obesity and Disease in Previous Periods (Controlling for economic determinants)

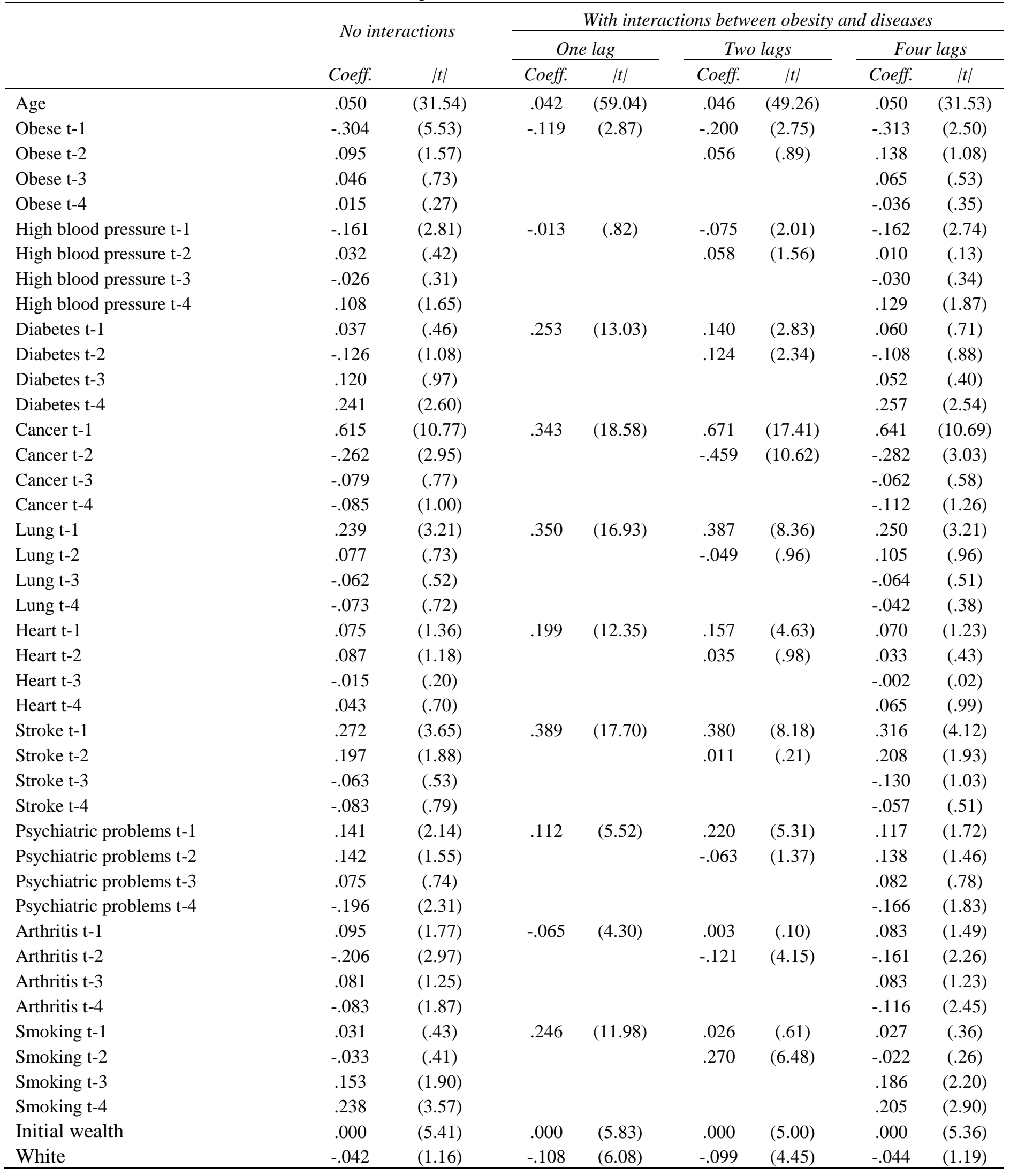




\begin{tabular}{|c|c|c|c|c|c|c|c|c|}
\hline Hispanic & -.080 & $(1.44)$ & -.149 & $(5.25)$ & -.146 & $(4.10)$ & -.087 & $(1.55)$ \\
\hline Female & -.209 & $(6.77)$ & -.277 & $(17.69)$ & -.254 & $(13.10)$ & -.203 & $(6.55)$ \\
\hline Years of education & -.006 & $(1.30)$ & -.012 & $(5.57)$ & -.012 & $(4.36)$ & -.006 & $(1.39)$ \\
\hline Initial income & .000 & $(2.54)$ & .000 & $(3.70)$ & .000 & $(3.25)$ & .000 & $(2.54)$ \\
\hline Initial experience & -.001 & $(1.42)$ & -.008 & $(16.33)$ & -.005 & $(9.20)$ & -.001 & $(1.28)$ \\
\hline Obesity x High blood pressure (t-1) & & & .030 & $(.74)$ & .004 & $(.06)$ & .018 & $(.16)$ \\
\hline Obesity x High blood pressure (t-2) & & & & & .015 & $(.24)$ & .111 & $(.94)$ \\
\hline Obesity x High blood pressure (t-3) & & & & & & & -.009 & $(.07)$ \\
\hline Obesity x High blood pressure (t-4) & & & & & & & -.087 & $(.85)$ \\
\hline Obesity x Diabetes (t-1) & & & -.012 & $(.31)$ & .031 & $(.50)$ & -.057 & $(.53)$ \\
\hline Obesity x Diabetes (t-2) & & & & & -.073 & $(1.16)$ & -.063 & $(.51)$ \\
\hline Obesity x Diabetes (t-3) & & & & & & & .204 & $(1.57)$ \\
\hline Obesity x Diabetes (t-4) & & & & & & & -.061 & $(.52)$ \\
\hline Obesity x Cancer (t-1) & & & -.083 & $(1.82)$ & -.184 & $(2.51)$ & -.145 & $(1.29)$ \\
\hline Obesity x Cancer (t-2) & & & & & .087 & $(1.12)$ & .174 & $(1.26)$ \\
\hline Obesity x Cancer (t-3) & & & & & & & -.235 & $(1.46)$ \\
\hline Obesity x Cancer (t-4) & & & & & & & .207 & $(1.34)$ \\
\hline Obesity x Lung (t-1) & & & -.105 & $(2.17)$ & -.050 & $(.64)$ & -.060 & $(.45)$ \\
\hline Obesity x Lung $(\mathrm{t}-2)$ & & & & & -.040 & $(.48)$ & -.148 & $(.90)$ \\
\hline Obesity x Lung (t-3) & & & & & & & .009 & $(.05)$ \\
\hline Obesity x Lung (t-4) & & & & & & & -.151 & $(.86)$ \\
\hline Obesity x Heart (t-1) & & & .086 & $(2.28)$ & .148 & $(2.48)$ & .002 & $(.02)$ \\
\hline Obesity x Heart (t-2) & & & & & .018 & $(.30)$ & .293 & $(2.59)$ \\
\hline Obesity x Heart (t-3) & & & & & & & -.070 & $(.61)$ \\
\hline Obesity x Heart (t-4) & & & & & & & -.087 & $(.80)$ \\
\hline Obesity x Stroke (t-1) & & & -.174 & $(3.16)$ & -.194 & $(2.26)$ & -.352 & $(2.37)$ \\
\hline Obesity x Stroke (t-2) & & & & & -.026 & $(.29)$ & -.083 & $(.48)$ \\
\hline Obesity x Stroke (t-3) & & & & & & & .395 & $(2.10)$ \\
\hline Obesity x Stroke (t-4) & & & & & & & -.080 & $(.43)$ \\
\hline Obesity x Psychiatric problems (t-1) & & & -.038 & $(.83)$ & -.125 & $(1.69)$ & .157 & $(1.30)$ \\
\hline Obesity x Psychiatric problems ( $\mathrm{t}-2)$ & & & & & .070 & $(.93)$ & .016 & $(.11)$ \\
\hline Obesity x Psychiatric problems (t-3) & & & & & & & -.060 & $(.38)$ \\
\hline Obesity x Psychiatric problems (t-4) & & & & & & & -.131 & $(.87)$ \\
\hline Obesity x Arthritis (t-1) & & & -.041 & $(1.07)$ & -.022 & $(.36)$ & .082 & $(.76)$ \\
\hline Obesity x Arthritis (t-2) & & & & & .040 & $(.70)$ & -.306 & $(2.67)$ \\
\hline Obesity x Arthritis (t-3) & & & & & & & -.035 & $(.30)$ \\
\hline Obesity x Arthritis (t-4) & & & & & & & .227 & $(2.39)$ \\
\hline Obesity x Smoking (t-1) & & & .007 & $(.14)$ & -.033 & $(.37)$ & .034 & $(.22)$ \\
\hline Obesity x Smoking (t-2) & & & & & -.038 & $(.47)$ & -.086 & $(.54)$ \\
\hline Obesity x Smoking (t-3) & & & & & & & -.195 & $(1.27)$ \\
\hline Obesity x Smoking (t-4) & & & & & & & .197 & $(1.52)$ \\
\hline Constant & -5.188 & $(36.20)$ & -4.207 & $(65.98)$ & -4.594 & $(54.63)$ & -5.214 & $(36.04)$ \\
\hline \multicolumn{9}{|l|}{ Sum of interaction by disease } \\
\hline High blood pressure & & & .030 & $(.74)$ & .019 & $(.34)$ & .033 & $(.35)$ \\
\hline Diabetes & & & -.012 & $(.31)$ & -.042 & $(.79)$ & .023 & $(.24)$ \\
\hline Cancer & & & -.083 & $(1.82)$ & -.097 & $(1.50)$ & .001 & $(.01)$ \\
\hline Lung & & & -.105 & $(2.17)$ & -.090 & $(1.33)$ & -.350 & $(2.43)$ \\
\hline
\end{tabular}




\begin{tabular}{|c|c|c|c|c|c|c|c|}
\hline Heart & & .086 & $(2.28)$ & .165 & $(3.24)$ & .139 & $(1.47)$ \\
\hline Stroke & & -.174 & (3.16) & -.221 & $(2.81)$ & -.119 & $(.78)$ \\
\hline Psychiatric problems & & -.038 & $(.83)$ & -.055 & $(.87)$ & -.018 & $(.15)$ \\
\hline Arthritis & & -.041 & (1.07) & .017 & $(.32)$ & -.032 & $(.34)$ \\
\hline Smoking & & .007 & $(.14)$ & -.071 & $(.93)$ & -.050 & $(.37)$ \\
\hline Person-year observations & 37169 & \multicolumn{2}{|c|}{128199} & \multicolumn{2}{|c|}{83491} & \multicolumn{2}{|c|}{37169} \\
\hline
\end{tabular}

